\title{
Amyloid precursor protein in pancreatic islets
}

\author{
Joshua A Kulas, Kendra L Puig and Colin K Combs \\ Department of Biomedical Sciences, University of North Dakota School of Medicine and Health Sciences, \\ Grand Forks, USA
}

Correspondence should be addressed to $\mathrm{C} \mathrm{K}$ Combs

Email

colin.combs@med.und.edu

\begin{abstract}
The amyloid precursor protein (APP) has been extensively investigated for its role in the production of amyloid beta (A $\beta$ ), a plaque-forming peptide in Alzheimer's disease (AD). Epidemiological evidence suggests type 2 diabetes is a risk factor for $A D$. The pancreas is an essential regulator of blood glucose levels through the secretion of the hormones insulin and glucagon. Pancreatic dysfunction is a well-characterized consequence of type 1 and type 2 diabetes. In this study, we have examined the expression and processing of pancreatic APP to test the hypothesis that APP may play a role in pancreatic function and the pathophysiology of diabetes. Our data demonstrate the presence of APP within the pancreas, including pancreatic islets in both mouse and human samples. Additionally, we report that the APP/PS1 mouse model of AD overexpresses APP within pancreatic islets, although this did not result in detectable levels of $A \beta$. We compared whole pancreas and islet culture lysates by Western blot from C57BL/6 (WT), APP-/and APP/PS1 mice and observed APP-dependent differences in the total protein levels of GLUT4, IDE and BACE2. Immunohistochemistry for BACE2 detected high levels in pancreatic $\alpha$ cells. Additionally, both mouse and human islets processed APP to release SAPP into cell culture media. Moreover, sAPP stimulated insulin but not glucagon secretion from islet cultures. We conclude that APP and its metabolites are capable of influencing the basic physiology of the pancreas, possibly through the release of SAPP acting in an autocrine or paracrine manner.
\end{abstract}
Key Words
$\checkmark$ amyloid
- BACE2
- Alzheimer
- pancreas
- diabetes
- insulin

\section{Introduction}

Alzheimer's disease (AD) is a progressive neurodegenerative disease currently affecting 5.3 million Americans. By 2050, it is expected that the number of US citizens afflicted with AD will rise to 16 million (Alzheimer's Association 2015). Several lines of evidence indicate that metabolic dysfunction, insulin resistance and perturbations in cerebral glucose utilization may play a critical role in the disease process (Hoyer 1991, Biessels et al. 2006, De Felice \& Ferreira 2014, de la Monte 2014, Bedse et al. 2015). Type 2 diabetes, or insulin resistance, is reported to be a risk factor for developing dementia and evidence suggests insulin signaling dysfunction occurs in the brains of $\mathrm{AD}$ patients (Talbot et al. 2012, Crane et al. 2013).

One protein thought to be critical in the development of $\mathrm{AD}$ is $\mathrm{A} \beta$, a self-aggregating peptide cleaved from the larger amyloid precursor protein (APP) (Goldgaber et al. 1987, Selkoe etal.1988). APP is a single-pass transmembrane protein of uncertain function highly expressed in the CNS and detectable in many other cell types (Arai et al. 1991, Konig et al. 1992, Schlossmacher et al. 1992). It is cleaved by proteases such as beta-site amyloid precursor protein-cleaving enzyme 1 (BACE1) and gamma secretase 
to release N-terminal fragments (sAPP $\alpha$ and $\mathrm{SAPP} \beta$ ) and varying size $A \beta$ fragments (A $\beta$ 1-40 and $A \beta$ 1-42). Much of the research focused on APP biology has been in the context of $\mathrm{A} \beta$ plaque deposition in the central nervous system. However, it is known that higher-molecularweight isoforms of APP are present in many peripheral organs (Selkoe et al. 1988). Our recent work has focused on characterizing APP expression and function in several peripheral tissues including intestinal and adipose tissue (Sondag \& Combs 2010, Puig et al. 2012, 2015, Puig \& Combs 2013).

The pancreas has an essential role in the regulation of blood glucose levels, primarily through the secretion of the hormone insulin from pancreatic $\beta$ cells. Pancreatic dysfunction is a well-known consequence of both type 1 and type 2 diabetes (Ashcroft \& Rorsman 2012). Numerous studies in both primates and mice suggest that damaging or stressing the endocrine pancreas may promote changes in the central nervous system associated with the pathogenesis of AD (Ho et al. 2004, Julien et al. 2010, Takeda et al. 2010, Wang et al. 2010, MoralesCorraliza et al. 2016). Injections of insulin into a transgenic mouse model of $\mathrm{AD}$ have been shown to improve the memory of these mice as well as alter circulating concentrations of $\mathrm{A} \beta$ (Vandal et al. 2014). Administration of insulin into the brain intranasally is being explored as a cognitive enhancing therapeutic strategy in patients with AD (Reger et al. 2008, Holscher 2014, Claxton et al. 2015, Zhang et al. 2015).

Like $\mathrm{AD}$, diabetes has its own plaque pathology, in which the self-aggregating peptide amylin, or IAPP, is co-secreted with insulin and damages pancreatic islets (Westermark et al. 1987, Lorenzo et al. 1994). Whether A $\beta$ itself influences pancreatic IAPP aggregation through crossseeding or injures islets independently of IAPP remains uncertain. There are conflicting reports of the detection of amyloid beta within human islets (Miklossy et al. 2010, Oskarsson et al. 2015). Increased levels of $A \beta$ or $\mathrm{A} \beta$ aggregates have been detected within the pancreas of some transgenic mouse models of AD (Shoji et al. 1998, 2000, Wegiel et al. 2000, Vandal et al. 2015).

There is evidence that suggests that the endogenous functions of APP may be linked to the regulation of insulin secretion and signaling or whole body metabolism. The detection of APP has been reported in the exocrine and endocrine pancreas by immunohistochemistry and in situ hybridization, respectively (Beer et al. 1995, Figueroa et al. 2001). Additionally, a rigorous analysis of mice lacking APP $\left(\mathrm{APP}^{-/-}\right)$and/or the related APLP2 gene shows changes in circulating blood glucose concentrations
(Needham et al. 2008). Another report has suggested APP may directly regulate the process of insulin secretion from pancreatic islets (Tu et al. 2012). In this study, we examine murine and human pancreatic tissue to test the hypothesis that APP or A $\beta$ plays a role in pancreatic function or pathophysiology, respectively.

\section{Methods and materials}

\section{Animals}

The APP-knockout mice (APP-/-) strain B6.129S7-

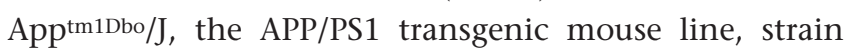
005864 B6.Cg-Tg (APPswe,PSEN1dE9)85Dbo/Mmjax and wild-type mouse line, C57BL/6, were purchased from the Jackson Laboratory (Bar Harbor, Maine). The APP-/- mice have the APP gene knocked out in the entire organism by the insertion of a neomycin resistance cassette into the promoter region and Exon 1 of the APP gene. The APP/PS1 mice express the Swedish mutation in APP and deltaE9 mutation in the PS1 gene under the control of the mouse prion promoter. APP/PS1 mice have been shown to develop $\mathrm{AD}$-like $\mathrm{A} \beta$ plaques within the brain around 6 months of age. Females from all three strains of mice were collected at 2 and 12 months of age for analysis.

\section{Animal use}

All animal use was approved by the University of North Dakota Institutional Animal Care and Use Committee (UND IACUC) protocols 1505-4 and 0712-1C. Mice were provided food and water ad libitum and housed in a 12-h light/ darkness cycle. The investigation conforms to the National Research Council of the National Academies Guide for the Care and Use of Laboratory Animals (8th edition).

\section{Human tissue}

Acetone-fixed $10 \mu \mathrm{m}$ healthy and diseased human pancreatic tissue sections were obtained from BioChain (Newark, CA, USA). Isolated pancreatic islets were obtained from Prodo Labs (Aliso Viejo, CA, USA). Tissue use was approved by the UND Institutional Review Board (protocol IRB-200412-198).

\section{Western blots}

Whole pancreas, isolated murine islets and isolated human islets were lysed in RIPA buffer containing protease

Published by Bioscientifica Ltd. 
inhibitor (Sigma P8340) on ice. Protein concentrations were determined using the Bradford method (Bradford 1976). 5-20 $\mu$ g of protein were resolved by $10 \%$ SDS-PAGE, transferred to PVDF membranes and Western blotted with chemiluminescent visualization.

\section{Antibodies}

Antibodies against full-length APP (ab32136), BACE2 (ab8025), glucagon (ab10988), IDE (ab32216) and the insulin receptor (ab69508) were purchased from Abcam. Antibodies against insulin (L6B10), p-GSK3 $\beta$ (D3A4), GSK3 $\beta$ (D5C5Z), p-AKT (193H12) and AKT (C67E7) were purchased from Cell Signaling Technology, Inc. The monoclonal 4G8 antibody targeting the $\mathrm{A} \beta$ peptide used in these studies was purchased from Covance (Princeton, NJ, USA) and is now available from Biolegend (San Diego, CA, USA). Antibodies against the N-terminus of APP (MAB348), GLUT2 (07-1402) and GLUT4 (07-1404) were purchased from Millipore (Darmstadt, Germany). Antibodies against GLUT1 (sc-7903), GLUT3 (sc-7682) and ZNT8 (sc-98243) were purchased from Santa Cruz Biotechnology, Inc. The antibody for amylin (250470) was purchased from Abbiotec (San Diego, CA, USA). The antibody against human APP (803001) was purchased from Biolegend (San Diego, CA, USA). The antibody against $A \beta$ oligomers (11610) was purchased from Cayman Chemical. The antibody against neprilysin (MAB1126) was purchased from R\&D Systems.

\section{Immunohistochemistry/immunofluorescence}

Pancreatic tissue was fixed in $4 \%$ paraformaldehyde (PFA) and cut into $10 \mu \mathrm{m}$ serial sections by cryostat. Mouse brains were fixed in 4\% PFA, embedded in gelatin and serial sectioned to a thickness of $40 \mu \mathrm{m}$ using a sliding microtome. The tissue was incubated overnight in primary antibody diluted in a PBS-based solution (1\% Triton X-100, 3\% BSA, 2\% horse serum). Vector VIP (Vector Labs, Burlingame, CA, USA) was used as the chromogen for visible light microscopy. For immunofluorescent co-localization, Alexa Fluor 594 and Alexa Fluor 488 conjugated secondary antibodies (Life Technologies) were used with a DAPI counterstain. Nonspecific binding of secondary antibodies was assessed by applying only the secondary antibody in blocking PBS solution. BACE2 epitope blocking peptide studies were conducted by incubating tissue with $1 \mu \mathrm{g} / \mathrm{mL}$ anti-BACE2 antibody with or without $2 \mu \mathrm{g} / \mathrm{mL}$ BACE2 blocking peptide (Abcam ab8392). BACE2 staining was quantified by using Photoshop CS6 software. Images of islets were converted to greyscale and traced around the periphery to assess total islet BACE2 staining intensity. The total islet staining intensity was divided by the total area assessed to normalize for islet size. A total of twelve nonserial sections from 12-month-old animals $(n=8)$ from each strain were stained and assessed in this manner. A minimum of twenty islets from each strain of mice was analyzed for its BACE2 staining intensity. Values obtained from this analysis were normalized to the mean staining intensity value of the wild-type strain.

\section{Thioflavin S staining}

Thioflavin S staining was optimized in APP/PS1 mouse brain tissue and then performed in pancreatic tissue by first quenching endogenous fluorescence by incubating slides in $0.2 \%$ Sudan Black dissolved in 50\% ethanol for $5 \mathrm{~min}$. Slides were then washed in PBS and then incubated in $0.02 \%$ thioflavin $\mathrm{S}$ dissolved in $\mathrm{dH}_{2} \mathrm{O}$ for $30 \mathrm{~min}$. Slides were washed again in PBS then dehydrated and coverslipped in Permount.

\section{Enzyme-linked immunosorbent assays (ELISA)}

Human A $\beta$ ELISA kits (Millipore) were utilized for quantitation of tissue and islet culture $A \beta$. Whole pancreas tissue was lysed in radioimmunoprecipitation assay buffer (RIPA) to yield detergent soluble $A \beta . A \beta$ in islet cultures was assessed by hand picking islets directly from culture and lysing 20 islets of similar size from each animal in $100 \mu \mathrm{L}$ SDS-free Triton X-100 buffer. This lysate was then pulse sonicated and the lysate $\mathrm{A} \beta$ was immediately measured by ELISA. To assess islets for quantitation of total pancreatic insulin and insulin secretion from murine islets, a mouse insulin ELISA kit (Millipore ZRMI-13K) was used. Total pancreatic glucagon content was assessed using a glucagon ELISA kit (R\&D Systems). Tissue samples were normalized by total sample protein as determined by the Bradford method. Human islet insulin secretion was quantified using a human insulin ELISA kit (Invitrogen KAQ12511). ELISAs were performed as recommended by the manufacturer's instructions.

\section{Pancreatic islet isolation and culture}

Pancreatic islets were isolated from $\mathrm{C} 57 \mathrm{BL} / 6$ and transgenic mice using modifications of prior methods

Published by Bioscientifica Ltd 
(Szot et al. 2007, Stull et al. 2012) The pancreas was first perfused by cannulating the bile duct with a combination of $1 \mathrm{mg} / \mathrm{mL}$ collagenase and thermolysin (products C9407 and P1512, Sigma Aldrich) in a sterile HBSS solution. The hepatic bile duct was closed using silk sutures prior to protease injection to direct fluid into the pancreas. Whole pancreas was then removed and placed in $50 \mathrm{~mL}$ tubes containing HBSS on ice. To initiate digestion, the tubes were then placed in a $37^{\circ}$ water bath and digestion was monitored with intermittent mechanical disruption. After approximately 10-15 min, islets were then isolated from crude tissue extract by density centrifugation along a Histopaque (Sigma Aldrich) gradient before further purification using $70 \mu \mathrm{m}$ filters. Islets from individual animals were cultured separately in RPMI-1640 (Sigma Aldrich) containing $5 \mathrm{mM}$ glucose, 10\% FBS, 1\% glycine and $1 \%$ penicillin/neomycin/streptomycin. Human cadaveric pancreatic islets were obtained from Prodo Labs and cultured in RPMI-1640 (Sigma Aldrich) containing $5 \mathrm{mM}$ glucose, 10\% FBS, 1\% glycine and 1\% penicillin/ neomycin/streptomycin for $24 \mathrm{~h}$ before experiments were conducted.

\section{Min6 cell line culture and glucose-stimulated insulin secretion (GSIS) assay}

The murine MIN6 beta cell line was purchased from Addexbio Technologies (San Diego, CA, USA). MIN6 cells were cultured in DMEM/F12 media (Thermo Fisher Scientific) supplemented with 15\% FBS and $0.05 \mathrm{mM}$ 2-mercaptoethanol. MIN6 pseudoislets were produced by seeding MIN6 cells in low-attachment cell culture plates (Product \#3471) (Corning Incorporated). Three days after seeding and pseudoislet formation, MIN6 pseudoislets were utilized in a GSIS assay. Pseudoislets were first removed from cell culture media by wheel pipette and placed into Krebs Ringer buffer $(137 \mathrm{mM} \mathrm{NaCl}, 4.7 \mathrm{mM} \mathrm{KCl}, 1.2 \mathrm{mM}$ $\mathrm{KH}_{2} \mathrm{PO}_{4}, 1.2 \mathrm{mM} \mathrm{MgSO}_{4}, 2.5 \mathrm{mM} \mathrm{CaCl}, 25 \mathrm{mM} \mathrm{NaHCO}$ ) containing $.05 \% \mathrm{BSA}$ and $3.7 \mathrm{mM}$ glucose for $60 \mathrm{~min}$. Following incubation, pseudoislets were placed in fresh Ringer buffer and then ten pseudoislets of similar size were selected by wheel pipette and placed into $1.5 \mathrm{~mL}$ tubes containing $300 \mu \mathrm{L}$ Krebs Ringer Buffer with 3.7 or $16.7 \mathrm{mM}$ glucose and $0.05 \%$ BSA. For SAPP $\alpha$ (Product S9564, St. Louis, MO, USA) stimulation experiments, the glucose solution was supplemented with 1 or $10 \mathrm{nM}$ sAPP $\alpha$. After $1 \mathrm{~h}$ of stimulation, supernatants were collected and frozen at $-80^{\circ}$. Insulin concentration was determined in supernatants using mouse insulin ELISA kit (Millipore ZRMI-13K).

\section{Human and mouse primary islet culture glucose- stimulated insulin secretion (GSIS) assay}

Human or murine islets were cultured for $24 \mathrm{~h}$ in RPMI1640 with $5 \mathrm{mM}$ glucose and 10\% FBS. Islets were hand-picked from culture and incubated for $1 \mathrm{~h}$ prior to the GSIS assay in Krebs Ringer buffer $(137 \mathrm{mM} \mathrm{NaCl}$, $4.7 \mathrm{mM} \mathrm{KCl}, 1.2 \mathrm{mM} \mathrm{KH}_{2} \mathrm{PO}_{4}, 1.2 \mathrm{mM} \mathrm{MgSO}_{4}, 2.5 \mathrm{mM}$ $\mathrm{CaCl}_{2}, 25 \mathrm{mM} \mathrm{NaHCO}_{3}$ ) containing .05\% BSA and $3.7 \mathrm{mM}$ glucose. Following incubation, the islets were placed in fresh Ringer buffer. 8-10 islets/experiment were then hand selected and placed into sterile $1.5 \mathrm{~mL}$ tubes containing $300 \mu \mathrm{L}$ Krebs Ringer Buffer with glucose and BSA. For sAPP $\alpha$ (Product S9564) stimulation experiments, the glucose solution was supplemented with $10 \mathrm{nM}$ sAPP $\alpha$. For human islet stimulations, a range of glucose concentrations were used $(3.7,10$, and $16.7 \mathrm{mM}$ ) to span from low to high concentrations. Due to limitations in animal numbers of the WT, APP-/and APP/PS1 genotypes as well as the increased time required to hand select islets from the 3 genotypes for multiple conditions in the time-sensitive GSIS assay, we chose the $5 \mathrm{mM}$ glucose concentration for the murine islet stimulation since it is physiologically relevant, and we had observed the strongest and most consistent effect of sAPP stimulation of human islets near this concentration. After one hour, supernatants were frozen at $-80^{\circ}$. Samples were thawed and diluted using sterile Ringer's buffer prior to ELISA.

\section{Glucose tolerance testing}

Two-month-old WT, APP-/- and APP/PS1 animals were fasted for $5 \mathrm{~h}$ before receiving $2 \mathrm{~g} / \mathrm{kg}$ glucose by oral gavage. Prior to gavage and at times $15 \mathrm{~min}, 30 \mathrm{~min}$, one hour and two hours after gavage, blood glucose was measured by tail clipping and the TRUEresult glucometer (Home Diagnostics, Inc, Fort Lauderdale, FL, USA)

\section{Statistical analysis}

Statistical analysis was performed using SigmaPlot 12.0 software. Values were averaged +/-S.D. and statistical significance was determined via one-way ANOVA, twoway ANOVA or $t$-test, as appropriate. In the case of statistical significance, the Turkey-Kramer post hoc test or Holm-Sidak multiple pairwise comparisons were used where applicable.

Published by Bioscientifica Ltd 


\section{Results}

\section{APP was expressed within the endocrine pancreas}

To begin studying APP in the pancreas, we examined whole pancreatic tissue collected from two-month-old wild-type C57B6 (WT), APP-/- and APP/PS1 mice. The APP-/- animals have the APP gene knocked out in all tissues. APP/PS1 mice overexpress both human APP and the Presenilin-1 protein under the control of the prion promoter. This leads to high transgene expression in the central nervous system and results in $\mathrm{A} \beta$ plaque deposition in the brain with age. Pancreatic protein lysates were resolved by $10 \%$ SDS-PAGE and immunoblotted to compare expression of APP (Fig. 1A). APP was detected in wild-type pancreas, absent in APP-/- tissue and overexpressed in APP/PS1 mice. However, the human APP695 transgene migrated at an apparent lower molecular weight than endogenous mouse APP, consistent with reported expression of higher-molecular-weight isoforms in peripheral tissues (Selkoe et al. 1988).

In order to determine which cell types were expressing APP, immunohistochemistry was next performed. Pancreas from both two- and twelve-month-old WT, APP-/- and APP/PS1 mice was serial sectioned and stained using antibodies against the c-terminus of APP (Fig. 1B). Endogenous APP immunoreactivity localized to both endocrine and exocrine pancreas, with clear immunoreactivity in pancreatic islets at 12 months of age. APP immunoreactivity in the APP/PS1 transgenic mice robustly localized to islets at either age.

Following our investigation of murine tissue, we determined whether human pancreatic islets also expressed APP. Immunohistochemistry was performed on healthy, type 2 diabetes and cancerous human pancreatic tissue using antibodies directed against the c-terminus of APP. Similar to the mouse tissue findings, we observed clear APP immunoreactivity within the endocrine pancreas of all three tissue types (Fig. 1C). Pancreatic adenocarcinoma samples showed particularly robust APP islet immunoreactivity (Fig. 1C, Supplementary Fig. 1, see section on supplementary data given at the end of this article). This is in agreement with a number of studies demonstrating upregulated APP in pancreatic cancer where it may play a role in the disease process (Hansel et al. 2003, Woods \& Padmanabhan 2013).

The islet-enriched APP immunoreactivity was validated by Western blot analysis from both murine and human islet cultures. Islets grown from WT, APP-/- and APP/PS1 mice demonstrated the expected increase in APP expression in the APP/PS1 line with no detectable APP in the APP-/- mice (Fig. 1D). Human islet cultures also demonstrated robust APP levels via Western blot analysis (Fig. 1D).

Pancreatic islets are primarily composed of insulinproducing $\beta$ cells. To determine whether APP localized within these specialized cells, we next examined pancreas from the APP/PS1 mouse by immunofluorescence using primary antibodies against APP and insulin. APP immunoreactivity was highly localized to the insulinproducing cells in the APP/PS1 mice (Fig. 2A). Using the same approach, we confirmed that APP localized to $\beta$ cells of the human pancreas (Fig. 2B).

\section{Pancreatic APP was not processed to A $\beta$}

The presence of $A \beta$-containing plaques has been reported in the pancreas of some strains of transgenic mice although evidence of $\mathrm{A} \beta$ in human pancreas is conflicting (Miklossy et al. 2010, Oskarsson et al. 2015). To determine whether $A \beta$ was present in our transgenic samples, we utilized two methods, ELISA and immunohistochemistry, to detect $A \beta$ in mouse and human pancreas. Human $A \beta$ 1-40 and 1-42 was quantified by ELISA from WT, APP-/and APP/PS1 hippocampus, pancreas and primary islet culture lysates from twelve-month-old animals (Fig. 3A). Interestingly, while high concentrations of human $\mathrm{A} \beta$ were detectable in the brain lysates of APP/PS1 transgenic animals, we did not detect a significant increase in $\mathrm{A} \beta$ in the pancreas or islet lysate of these animals. Taken together, these data suggest that APP is processed by alternative mechanisms in the pancreas as compared to brain.

To further investigate the possibility of pancreatic A $\beta$ production, we utilized immunohistochemistry to stain for $A \beta$. Since we and others have previously observed that the APP/PS1 line accumulates brain A $\beta$ deposits in an age-dependent manner (Gordon et al. 2002, Manocha et al. 2016), WT and transgenic mouse pancreas were immunostained to detect $A \beta$ at two and twelve months of age (Fig. 3B). A faint amount of immunoreactivity was observed in 12-month-old $\mathrm{APP} / \mathrm{PS} 1$ islets relative to the $\mathrm{APP}^{-/-}$and WT mice likely due to the anti-A $\beta$ antibody, 4G8, cross-reacting with fulllength APP. However, there were clearly no distinct signs of $\mathrm{A} \beta$ plaque deposition in either the two- or twelve-monthold mouse pancreas. We also examined healthy, type 2 diabetes and adenocarcinoma human pancreas tissue for $\mathrm{A} \beta$ immunoreactivity as well as for nonspecific amyloids 
A

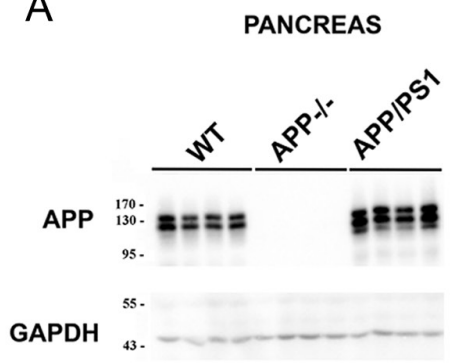

B

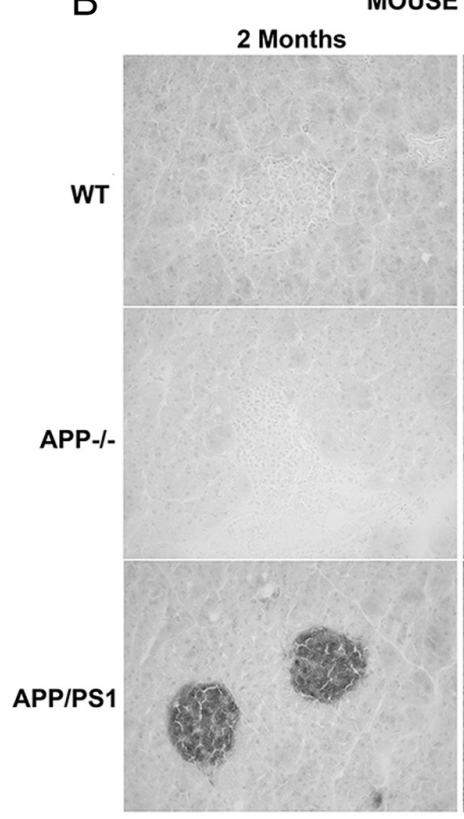

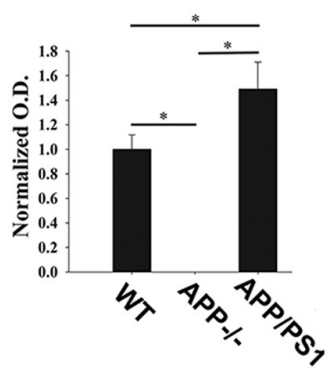

12 Months

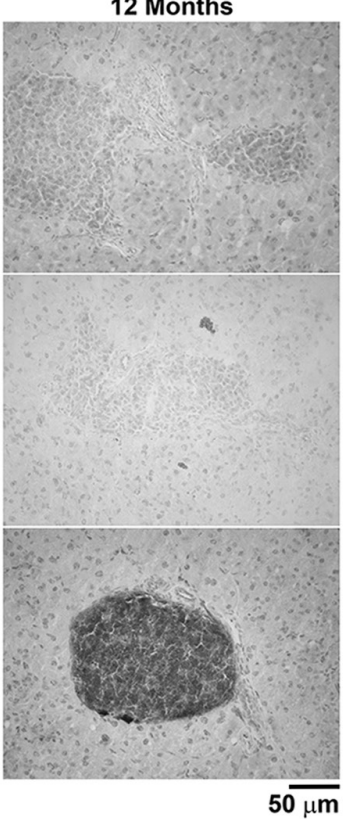

C

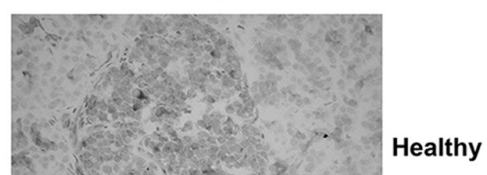

Healthy

T2D

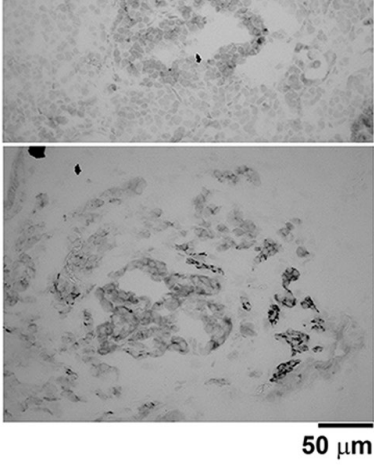

D

MOUSE ISLETS

HUMAN ISLETS

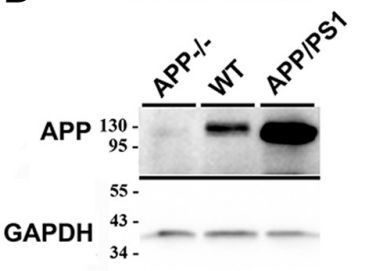

Adenocarcinoma

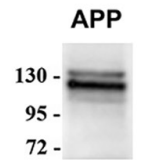

\section{Figure 1}

Amyloid precursor protein was detected in mouse and human pancreas including islets of Langerhans. (A) Whole pancreas was collected from C57BL/6 (WT), APP $-1-$ and APP/PS1 mice $(n=7)$ and lysed in RIPA buffer. $20 \mu \mathrm{g}$ of protein were resolved by 10\% SDS-PAGE and Western blotted using anti-APP (Y188) antibody or anti-GAPDH antibody as a loading control. Normalized optical density was averaged \pm S.D., $* P<0.05$. (B) Pancreas was harvested from C57BL/6 (WT), APP/PS1 and APP-/- at 2 months $(n=7)$ and 12 months $(n=4)$ of age. Tissue was fixed in $4 \%$ paraformaldehyde and cryosectioned into $10 \mu \mathrm{m}$ serial sections. Immunohistochemistry was performed using anti-APP (Y188) antibody. Vector VIP was used as the

chromogen. (C) Immunohistochemistry was performed on human pancreatic tissue. Pancreas from a healthy 77-year-old male donor, 68-year-old male type 2 diabetic donor and a 66-year-old male with pancreatic adenocarcinoma was probed using anti-APP antibody (Y188) with vector VIP used as the chromogen. (D) Representative Western blot of protein lysates from cultured pancreatic islets from WT, APP-/- and APP/PS1 mice. Islet protein was resolved by $10 \%$ SDS-PAGE, transferred to PVDF and immunoblotted using anti-APP antibody (Y188). Islets from a healthy 55-year-old male donor were cultured, and then lysed in RIPA buffer and resolved using 10\% SDS-PAGE, and then transferred to PVDF membrane and Western blotted using anti-APP antibody, 22C11.

by thioflavin staining (Fig. 3B, Supplementary Fig. 2). While thioflavin $S$ stained several areas of both healthy and type two diabetic pancreas, no detectable $A \beta$ plaquelike deposits were observed although some scattered puncta, which may correspond to A $\beta$ or sAPP were noted in all conditions, including within pancreatic islets. Following these negative results, we sought to determine if the methodology we employed was sufficient to detect amyloid deposits. We performed immunostaining for $\mathrm{A} \beta$ in addition to thioflavin S staining in 12-month WT and APP/PS1 mouse brain tissue sections (Supplementary Fig. 2). As expected, APP/PS1 brains showed abundant plaque deposition using both methods without detectable plaques in WT brains (Supplementary Fig. 2) in contrast to a clear lack of any plaque-like deposits in the pancreas (Fig. 3B). 

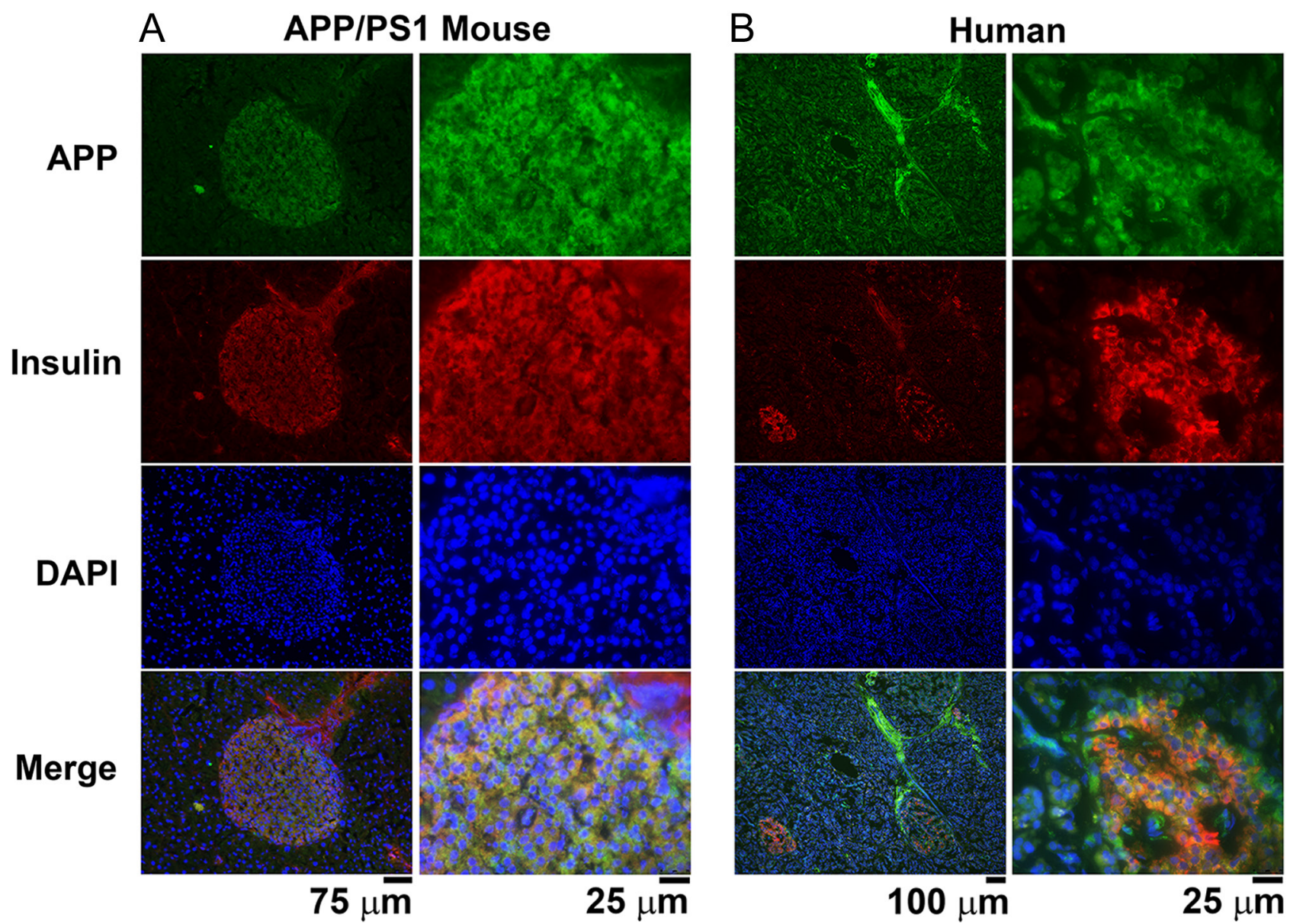

Figure 2

Amyloid precursor protein was detectable in the insulin-producing $\beta$ cells of the human pancreas and the APP/PS1 mouse. Immunofluorescent staining was performed using (A) APP/PS1 transgenic mouse and (B) human tissue cryosections (10 $\mu \mathrm{m})$. Anti-APP (Y188) and insulin primary antibodies with Alexa Flour 488 and Alexa Flour 594 fluorophore-conjugated secondary antibodies were used for visualization with DAPI counterstain.

\section{APP/PS1 mice showed no differences in glucose} tolerance testing or pancreatic insulin levels but had significantly decreased pancreatic glucagon compared to WT and APP-/- mice

An essential function of the pancreas is to regulate blood glucose levels. In order to test if differences in pancreatic islet APP content caused changes in whole body glucose tolerance, we subjected WT and transgenic animals to $2 \mathrm{~g} / \mathrm{kg}$ glucose challenge by oral gavage. Blood glucose measurements were taken from tail clipping after four hours of fasting and at 15, 30, 60 and 120 min after glucose challenge (Fig. 4A and B). Surprisingly, no differences were observed across genotypes. In addition to assessing glucose tolerance, we also homogenized whole pancreas from 2-month-old animals and assessed their insulin and glucagon content by ELISA (Fig. 4C and D). Glucagon concentrations from APP/PS1 pancreas were significantly lower than WT and APP-/- mice although no changes in insulin content were detected across genotypes. Based upon the glucagon differences, APP/PS1 pancreas tissue was fluorescently double labeled with anti-APP and glucagon antibodies. Although there were relatively few glucagon immunoreactive cells, it was clear that they colocalized with APP immunoreactivity suggesting that transgene expression alters the biology of these cells (Supplementary Fig. 3).

\section{APP expression modulated pancreatic BACE2, GLUT4 and} IDE levels in the transgenic mice

To better understand the contribution of APP expression to pancreatic physiology, we quantified protein levels from homogenized murine pancreas of WT and transgenic animals by Western blot with a particular focus on proteins involved in insulin signaling, glucose uptake and $A \beta$ degradation (Fig. 5). Although no changes in protein levels 
A

A $\beta$ ELISAs

MOUSE
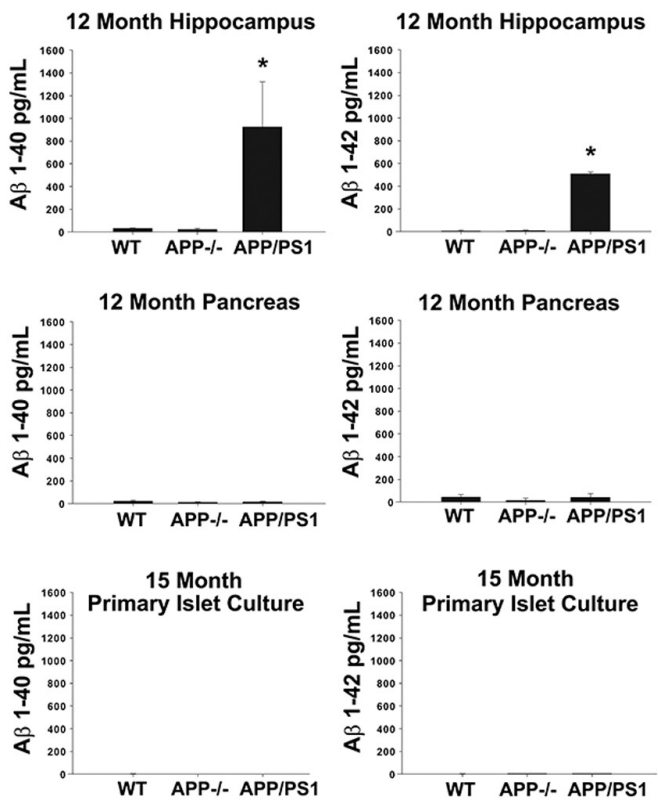

B
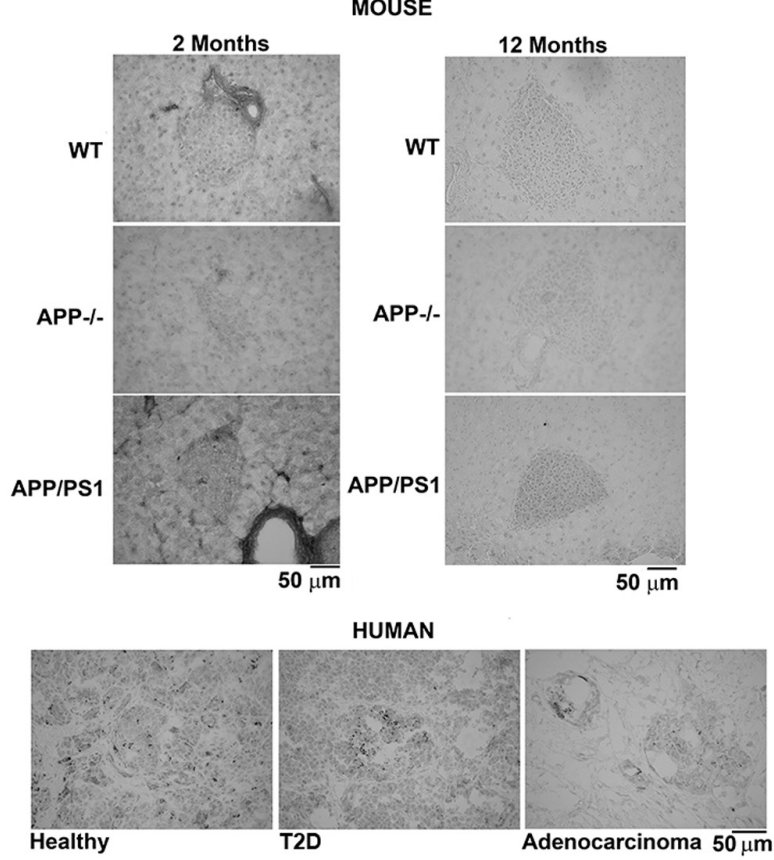

Figure 3

A $\beta$ was not detectable in mouse pancreas by immunohistochemistry or ELISA. (A) Mouse pancreas and hippocampus tissue was lysed in RIPA buffer ( $n=4 /$ strain), while islets ( $n=6 /$ strain) were pelleted and lysed in Triton X-100 buffer to yield detergent-soluble $A \beta$ extract. Extract was used to quantify both human $A \beta$ 1-40 and human A $\beta$ 1-42 by ELISA. APP-/- animals served as a negative control to measure the background of the assay. Data are expressed as mean values +/- s.D., $* P<0.05$ from WT. (B) Immunohistochemistry was performed on $10 \mu \mathrm{m}$ cryosections of WT, APP-/- and APP/PS1 murine pancreas as well as human healthy control, type 2 diabetes (T2D) and adenocarcinoma pancreas tissue. Anti-A $\beta$ antibody (4G8) was used with Vector VIP as the chromogen.

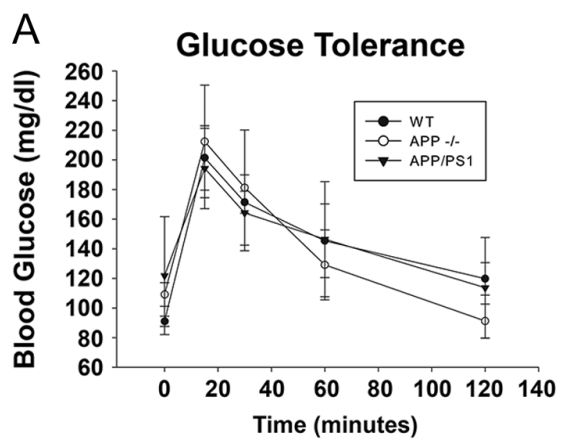

\section{Pancreatic Insulin Content}

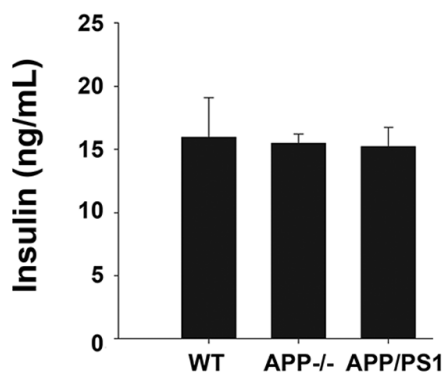

B

\section{Glucose Tolerance: AUC}

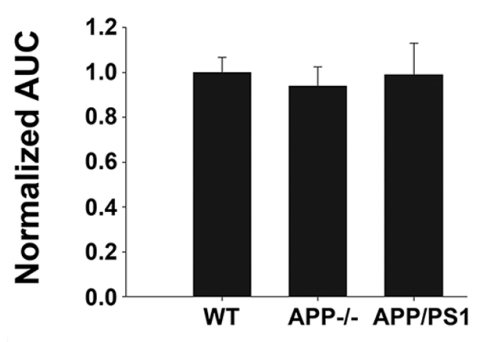

D Pancreatic Glucagon Content

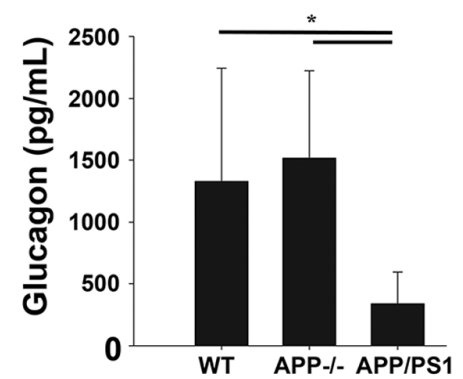

\section{Figure 4}

No difference in glucose tolerance or pancreatic insulin content was observed in 2-month-old APP-/- and APP/PS1 mice, but whole pancreas glucagon content was reduced in transgenic APP/ PS1 mice. 2-month-old WT, APP-/- and APP/PS1 mice were subjected to glucose tolerance testing. Prior to testing, mice were fasted four hours and then received $2 \mathrm{~g} / \mathrm{kg}$ glucose by oral gavage. (A) Blood glucose was measured at intervals by blood glucose meter $(n=4-7)$. (B) The area under the curve (AUC) from glucose tolerance testing of each mouse was measured and the results from each strain are graphed. Each strain was normalized to the mean AUC of the WT strain. Whole mouse pancreas was lysed using RIPA buffer. (C) Insulin ( $n=6-7)$ and (D) glucagon $(n=6-7)$ content were assessed by ELISA. Data are shown as mean values $+/-$ S.D., $* P<0.05$. 


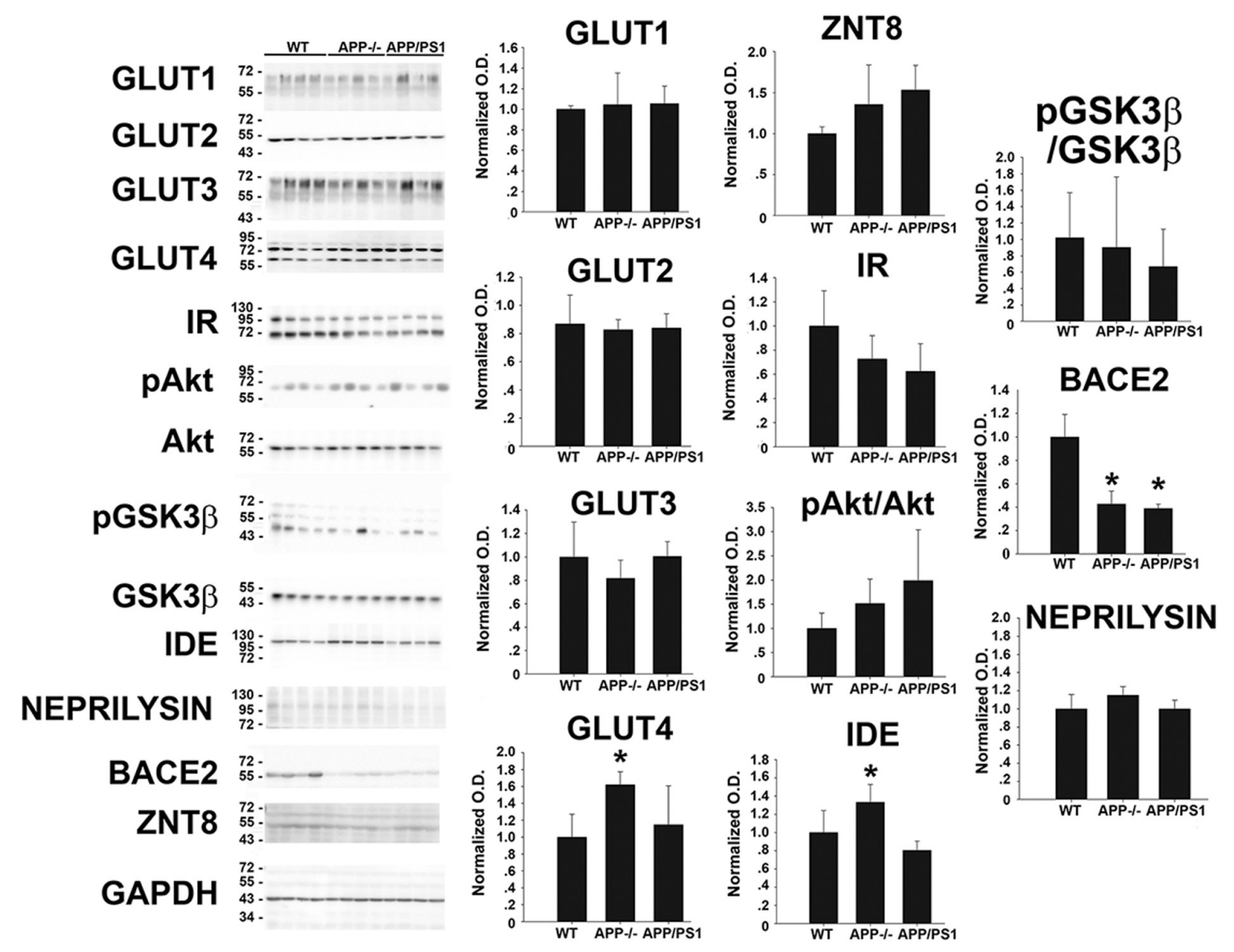

Figure 5

Differences in 2-month-old mouse pancreatic BACE2, IDE and GLUT4 were observed by Western blot. Whole pancreas from WT, APP-/- and APP/PS1 mice was lysed in RIPA buffer and resolved using 10\% SDS-PAGE. Protein was transferred to PVDF membrane and Western blotted for multiple proteins using GAPDH as a loading control. Optical density was measured and normalized to mean WT optical density $(n=7)$. Data are expressed as mean values $+/-$ s.D., $* P<0.05$.

of the glucose transporters GLUT1, GLUT2 or GLUT3 were observed across genotypes, protein levels of GLUT4 were significantly elevated in APP-/- mice compared to WT and APP/PS1 mice. No differences in insulin receptor (IR), pAkt or pGSK3 $\beta$ levels were observed. Similarly, total protein levels of zinc transporter 8 (ZNT8) did not differ across species. BACE2 has been suggested to both interact with APP in vitro as an $\alpha$-secretase and play a role in pancreatic insulin secretion through the cleavage of its substrate, TMEM27 (Yan et al. 2001, Esterhazy et al. 2011). We assessed BACE2 protein levels using an antibody against an amino acid sequence within the prodomain of BACE2 that is not found in BACE1 (Bennett et al. 2000). Strikingly, total protein levels of BACE2 were significantly reduced in $\mathrm{APP}^{-/-}$and APP/PS1 compared to WT indicating that APP may influence the expression or activity of BACE2 in the pancreas. Since both $A \beta$ and insulin are degraded by a common enzyme, insulin-degrading enzyme (IDE) (Qiu et al. 1998), we quantified IDE protein levels to observe a significant increase in APP-/- mice compared to all other genotypes. We also quantified protein levels of another A $\beta$ degrading enzyme, neprilysin, but detected no differences across genotypes. This suggested that APP has a role in regulating the expression of GLUT4, IDE and BACE2 in the pancreas.

BACE2 immunoreactivity was localized to islet periphery with decreased immunoreactivity in APP/PS1 mice with no concomitant increase in $A \beta$ immunoreactivity

Following our observation of changes in pancreatic BACE2 andIDE proteinlevels, weperformedimmunohistochemistry on 2-month-old WT and transgenic mouse pancreatic serial sections to determine where changes in protein expression localized (Fig. 6A). Increased immunoreactivity for IDE was observed in $\mathrm{APP}^{-/-}$tissue, with the higher levels of IDE observed in the acinar tissue of the pancreas. Immunohistochemistry for BACE2 using antibodies

Published by Bioscientifica Ltd. 
A

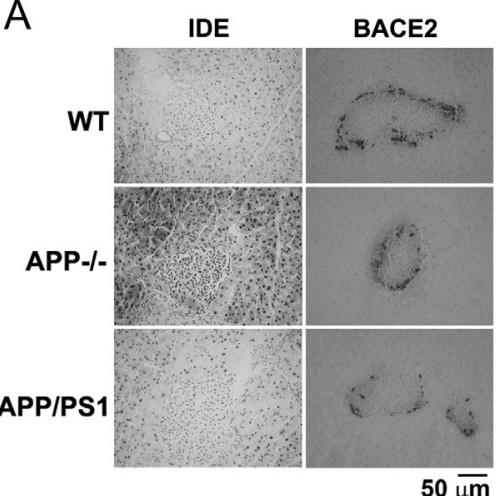

B

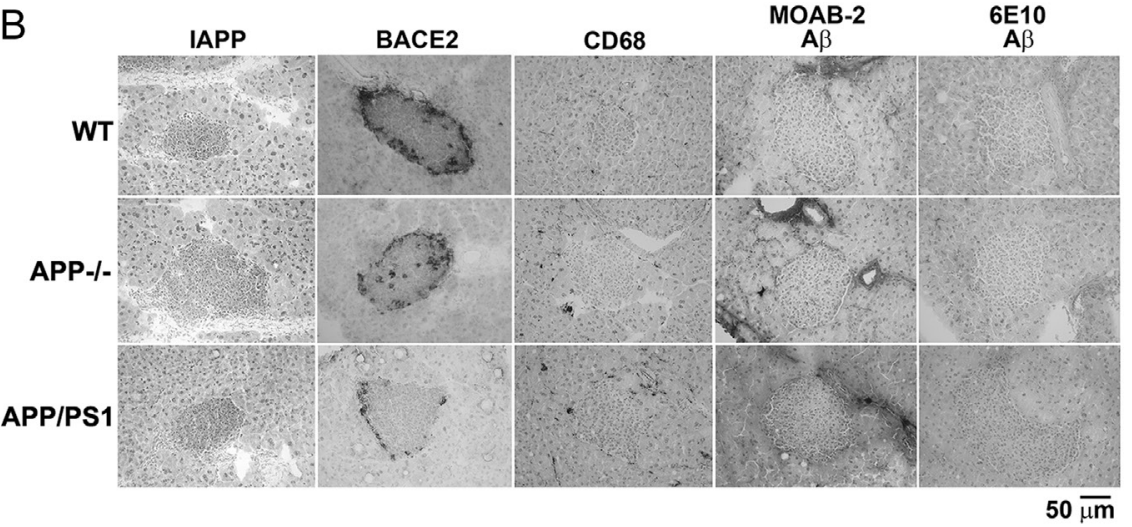

Figure 6

Immunohistochemistry of 2- and 12-month-old mouse pancreas. (A) Immunohistochemistry was performed on WT, APP-/- and APP/PS1 mouse 2-monthold $10 \mu \mathrm{m}$ pancreas cryosections using primary antibodies against IDE and BACE2 $(n=7)$. Tissue was fixed with $4 \%$ paraformaldehyde and Vector VIP chromogen was used as the chromogen. (B) Immunohistochemistry was performed on 12-month-old murine $10 \mu \mathrm{m}$ pancreas cryosections $(n=4)$. Primary antibodies against amylin/IAPP, BACE2, CD68, A $\beta$ oligomers (MOAB-2) and A $\beta$ were utilized to detect proteins. Vector VIP was used as the chromogen.

directed against the N-terminal prosequence revealed BACE2 expression within the endocrine pancreas, with the highest levels of immunoreactivity at the periphery of islets. In agreement with the Western blots, BACE2 immunoreactivity was notably less robust in APP/PS1 mice compared to WT. To validate this pattern of BACE2 tissue expression and further investigate APP processing within pancreatic islets, we performed immunohistochemistry on 12-month-old WT and transgenic mouse pancreas sections using primary antibodies against BACE2, IAPP, CD68 and A $\beta$ Glucagon (Fig. 6B, Supplementary Fig. 4) Immunohistochemistry for BACE2 revealed a similar pattern of protein expression at 12 months of age as was observed at 2 months, with the highest levels of BACE2 detected at the periphery of the islets. We further validated our BACE2 immunohistochemistry results by performing peptide blocking studies in mouse tissue to demonstrate the specificity of the BACE2 islet staining (Supplementary Fig. 4). Antibody pre-incubation with the BACE2 epitope blocking peptide completely abolished islet BACE2 staining at the islet periphery demonstrating our immunohistochemistry results are specific to the BACE2 epitope. We also quantified the intensity of BACE2 and glucagon immunoreactivity in mouse islets and observed significantly less BACE2 and glucagon staining in APP/PS1 mouse islets (Supplementary Fig. 4). No differences in IAPP/amylin aggregation were observed across mouse genotypes, which is as expected as mouse amylin is not known to form amyloid plaques. No $\mathrm{A} \beta$ plaque-like structures were detectable using antibodies against monomeric or oligomeric A $\beta$. Staining with anti-CD68 antibody to detect macrophages did not reveal any differences in islet macrophage infiltration suggesting local overexpression of APP within islets did not result in local $A \beta$-mediated immune activation as is known to occur in the central nervous system (Jimenez et al. 2008, Dhawan et al. 2012). As expected, mouse glucagon was localized primarily at the islet periphery.

\section{Immunohistochemistry for BACE2 demonstrated differential BACE2 localization in $\alpha$ and $\beta$ cells in both mouse and human tissue}

To determine the identity of the pancreatic islet cells stained positive for BACE2, we performed immunofluorescent double labeling of tissue from WT 2-month-old animals for BACE2 and either insulin or glucagon (Fig. 7A). Surprisingly, BACE2 immunoreactivity was highest in cells staining positive for glucagon suggesting BACE2 may be differentially active or expressed in pancreatic $\alpha$ compared to $\beta$ cells. The staining of $\alpha$-cells at the periphery of the islet is consistent with the known anatomical organization of murine pancreatic islets of Langerhans (Cabrera et al. 2006). Using this approach, we stained WT, APP-/- and APP/PS1 mouse pancreas for both BACE2 and insulin, and obtained complimentary results indicating the BACE2 enzyme localized within the islets and was more highly immunoreactive outside the insulinproducing cells at the periphery of the islets (Supplementary Fig. 5). We then co-labeled human pancreatic tissue for BACE2 and glucagon in the absence or presence of the BACE2 epitope blocking peptide to determine if BACE2 was also present in human $\alpha$ cells (Fig. 7B). Interestingly, we again observed robust BACE2 immunoreactivity in glucagonpositive cells, indicating this pattern of BACE2 expression is conserved across mouse and human $\alpha$ cells. Pre-incubation 
A

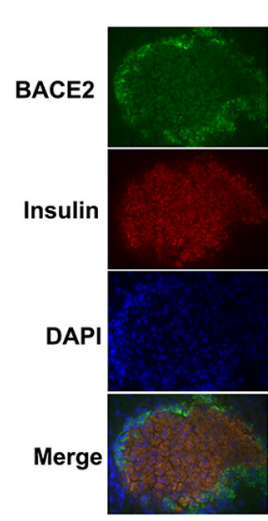

B

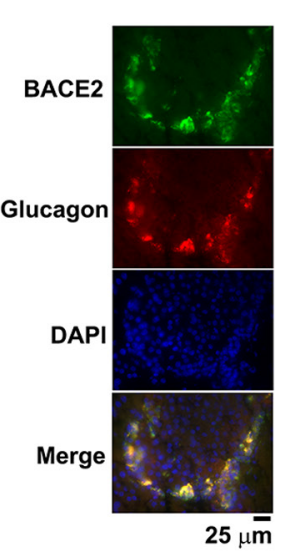

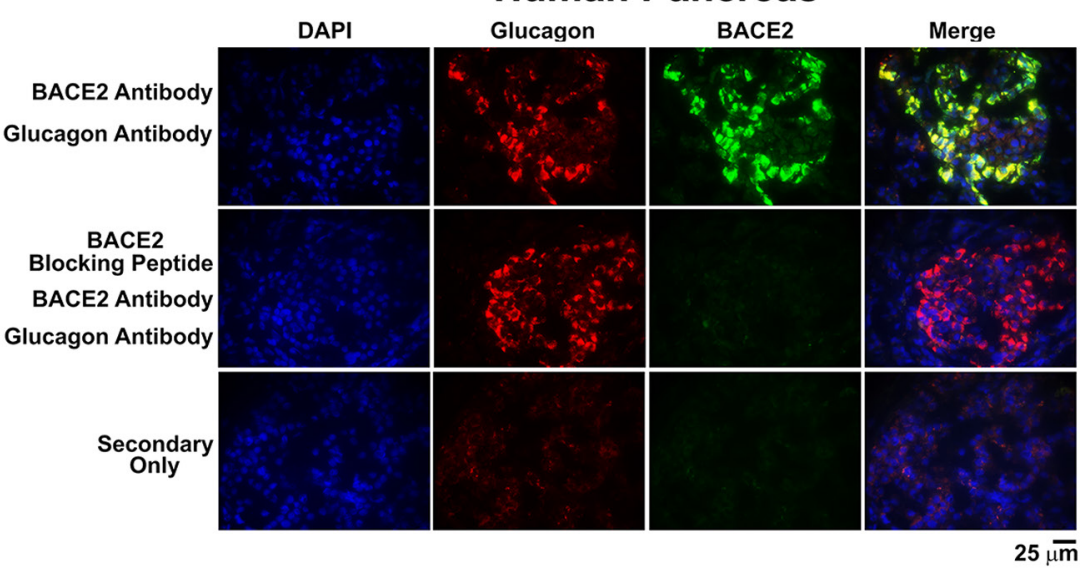

Figure 7

BACE2 was present in glucagon-positive cells. Immunohistochemistry was performed on (A) WT mouse and (B) human $10 \mu$ m pancreas cryosections using antibodies against BACE2 and insulin or glucagon with or without pre-incubation with BACE2 epitope blocking peptide. Fluorescent secondary antibodies were used for visualization (anti-rabbit Alexa Fluor 488 and anti-mouse Alexa Fluor 594). DAPI staining was used to visualize cell nuclei.

with the BACE2 epitope blocking peptide eliminated BACE2 immunoreactivity in $\alpha$ cells, indicating this antibody staining was specific to the BACE2 protein epitope.

\section{Primary murine islet cultures showed significant differences in APP and IDE content}

Only a small fraction of the pancreas is composed of hormone-secreting endocrine cells. To determine if protein differences observed in the whole pancreas lysate were due in part to differences in pancreatic islets, we cultured pancreatic islets isolated from WT, APP-/and APP/PS1 animals. We cultured these islets for $24 \mathrm{~h}$ and selected healthy islets of similar size for lysing and Western blot analysis (Fig. 8). We examined islet lysate for differences in APP, IDE, GLUT4 and BACE2 as differences in the levels of these proteins were observed in whole pancreas lysate. GAPDH was utilized as a loading control. As expected, APP was not detectable in APP-/- islets while APP/PS1 islets had high levels of APP. Surprisingly, like our whole pancreas extracts, IDE was significantly increased in $\mathrm{APP}-$ - islets compared to WT. We were unable to detect

\section{Primary Islet Cultures}

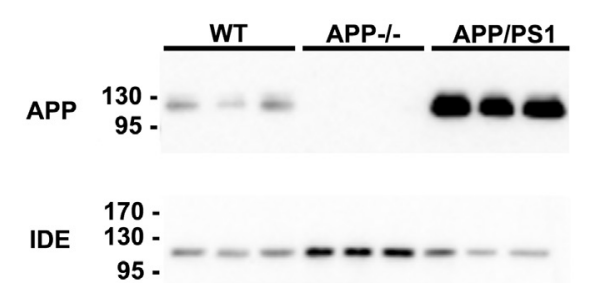

GLUT4 55

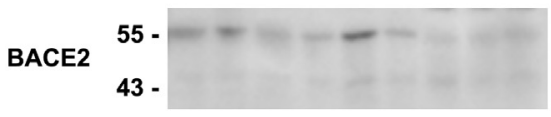

43 -

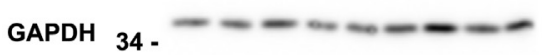

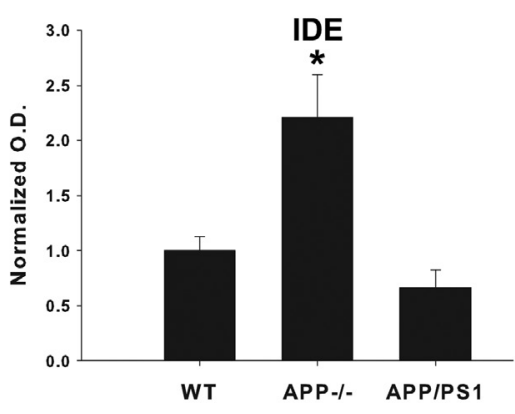

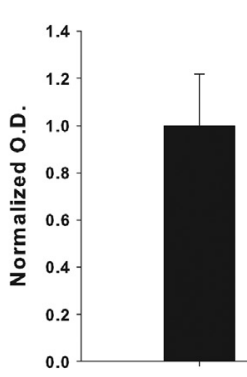

WT
BACE2

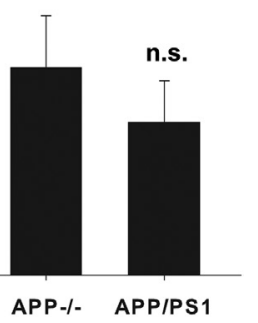

\section{Figure 8}

Western blots of 12-month-old mouse primary islet cultures. WT, APP-/- and APP/PS1 pancreatic islets $(n=3)$ were cultured overnight, and the next day, 50 islets from each animal were selected, pelleted and lysed in RIPA buffer. Protein lysate was resolved by $10 \%$ SDS-PAGE, and then transferred to PVDF membranes and Western blotted with antibodies against APP (Y188), IDE, GLUT4 and BACE2. Anti-GAPDH was used as a loading control. Optical density was measured for IDE and BACE2 and was normalized to WT optical density. Data are expressed as mean values \pm S.D., * $P<0.05$. 
GLUT4 in islet lysates. Islet BACE2 protein levels were not significantly different in transgenic animals compared to wild-type controls, in contrast to our immunostaining results. One possibility for this discrepancy is perhaps due to loss of peripheral islet cell integrity during the isolation or culture conditions we employed suggesting that further optimization is required in future work.

\section{APP was processed by $\alpha$-secretase activity in primary islet cultures and recombinant SAPP potentiated islet insulin but not glucagon secretion}

The presence of BACE2, as well as the lack of detectable $A \beta$, suggested that pancreatic APP was processed by a nonamyloidgenic pathway. It is known that sAPP is detectable in the conditioned media of cell cultures from a number of cell types (Weidemann et al. 1989). To determine if processing of pancreatic APP resulted in the release of sAPP into conditioned media, we grew primary cultures of both mouse and human pancreatic islets and collected the cells and conditioned media after $24 \mathrm{~h}$ for Western blot analysis (Fig. 9A). Both murine and human mutant APP were processed through the $\alpha$-secretase pathway resulting in the release of sAPP into culture media, including the human mutant APP expressed in APP/PS1 islets. Human sAPP $\alpha$ from APP/PS1 islets was detected using the 6E10 monoclonal antibody, which has been demonstrated to bind human sAPP (Bailey et al. 2008).

To better understand whether secreted sAPP $\alpha$ may have autocrine effects, we assessed insulin and glucagon secretion from primary cultures of isolated islets. A glucose-stimulated
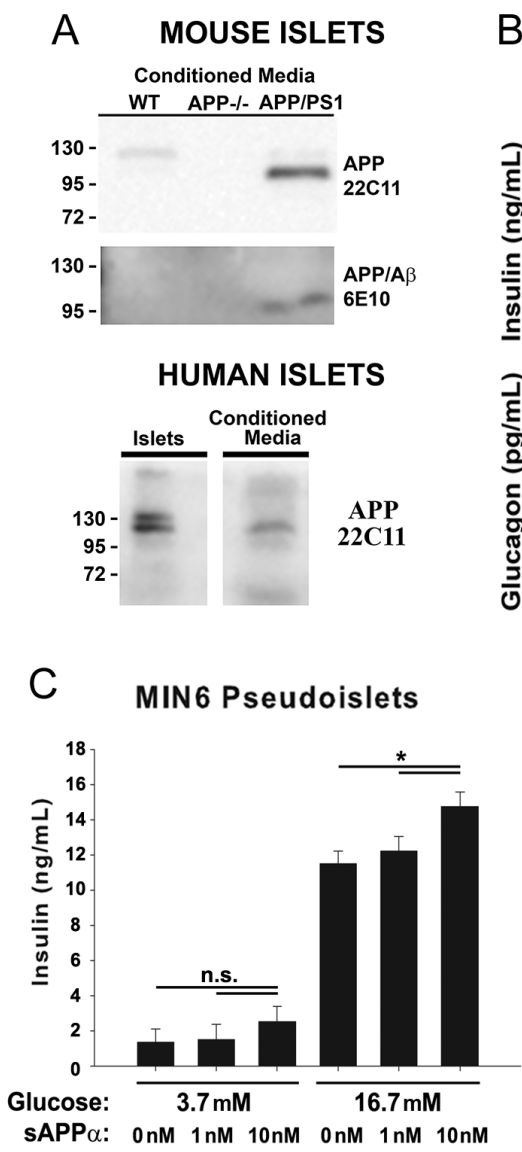

B
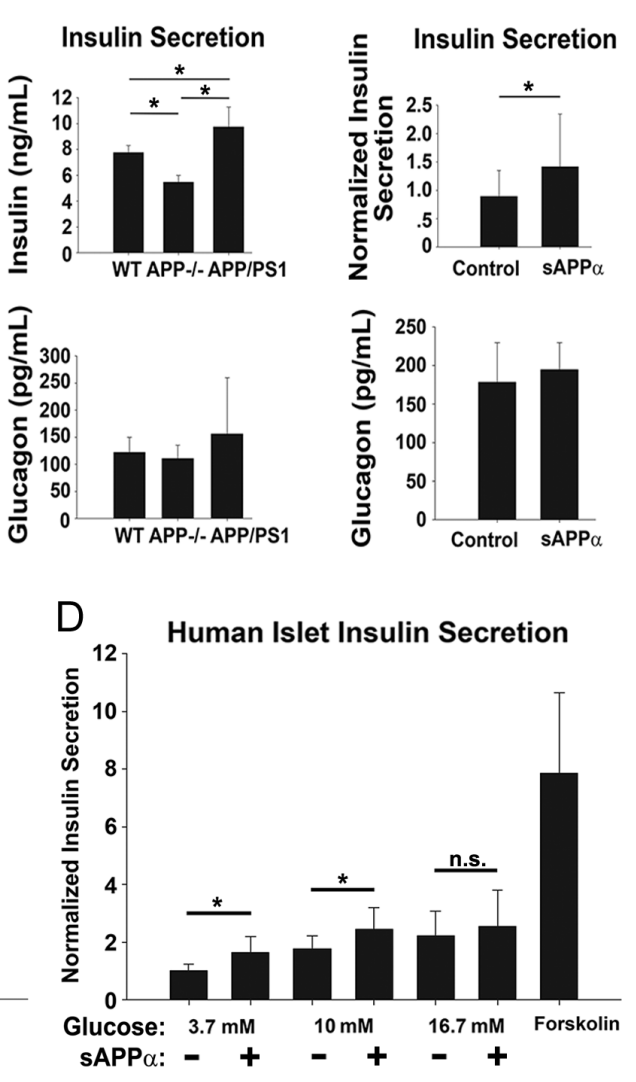

Figure 9

SAPP was released from primary murine and human islet cultures and recombinant SAPP $\alpha$ potentiated islet insulin secretion during glucose-stimulated insulin secretion assay. (A) Primary islet cultures from WT, APP-/- and APP/ PS1 mice were grown for $24 \mathrm{~h}$. Conditioned media was collected and protein content was assessed by Western blot using antibodies against N-terminal APP. 22C11 detects both mouse and human APP while 6E10 is specific to human APP and detects SAPP $\alpha$. Human islets were cultured for $24 \mathrm{~h}$ and both conditioned media collected for analysis by Western blot using anti N-terminal APP antibody (22C11). (B) Primary cultures of mouse islets were assessed for differences in insulin and glucagon secretion at $5 \mathrm{mM}$ glucose. Wild-type islets were stimulated with $10 \mathrm{nM}$ recombinant human SAPP $\alpha$ and supernatant was collected for insulin $(n=8)$ and glucagon $(n=4)$ ELISA. Insulin secretion data from multiple sAPP stimulation experiments were pooled by normalizing to the mean of the unstimulated control from each experiment. (C) The MIN6 insulin-secreting cell line was grown as pseudoislets and was stimulated with $0,1 \mathrm{nM}$ or $10 \mathrm{nM}$ recombinant SAPP $\alpha$ in GSIS assay at either $3.7 \mathrm{mM}$ or $16.7 \mathrm{mM}$ glucose ( $n=6-8$ /condition). Data are expressed as the mean \pm S.D., $* P<0.05$. (D) Human islets were treated with $10 \mathrm{nM}$ recombinant SAPP $\alpha$ during the GSIS assay in 3.7, 10 and $16.7 \mathrm{mM}$ glucose. After one hour of treatment, islet insulin secreted into the supernatant was assessed by ELISA. Data were pooled from five donors and normalized to basal insulin secretion at $3.7 \mathrm{mM}$. Data are expressed as the mean \pm S.D., $* P<0.05 .1 \mu \mathrm{M}$ forskolin was used with $16.7 \mathrm{mM}$ glucose to potentiate insulin secretion as a positive control. 
insulin secretion (GSIS) assay demonstrated significantly attenuated insulin secretion from APP-/- islets compared to WT and APP/PS1 while APP/PS1 islets had significantly higher insulin secretion compared to both WT and APP-/cultures (Fig. 9B). In order to determine whether the differences in insulin secretion could be related to SAPP $\alpha$, WT islet cultures were stimulated with recombinant sAPP $\alpha$ during the GSIS assay. In these studies, we utilized $10 \mathrm{nM}$ sAPP $\alpha$ for stimulations as this concentration has been shown to initiate signaling events in neuronal cells and is above the estimated $\mathrm{EC}_{50}$ of $2.3 \mathrm{nM}$ (Jimenez et al. 2011). Stimulation with SAPP $\alpha$ resulted in a significant but modest potentiation of islet insulin but not glucagon secretion (Fig. 9B).

This suggested that differences in basal insulin secretion from primary cultures of islets across genotype may be due, in part, to autocrine stimulation with sAPP $\alpha$. It also suggests that sAPP $\alpha$ has a role in particularly insulin biology of pancreatic islets or may support islet phenotype and survival in vitro.

Following our observation that SAPP $\alpha$ potentiates insulin secretion in cultures of primary mouse islets, we sought to further validate this finding by utilizing the MIN6 mouse $\beta$-cell line to test the effect of different doses of sAPP $\alpha$ and different concentrations of glucose on insulin secretion from MIN6 pseudoislets (Fig. 9C). Similar to our primary islet cultures, we observed that treatment with sAPP $\alpha$ modestly but significantly potentiated insulin secretion from MIN6 pseudoislets at $16.7 \mathrm{mM}$ glucose concentration. This effect was dose dependent, with $10 \mathrm{nM}$ but not $1 \mathrm{nM}$ recombinant sAPP $\alpha$ having a significant effect.

In order to further validate the findings from the mouse islets and MIN6 cells, we performed similar GSIS assays on human donor islets. Treatment of human islets with $10 \mathrm{nM}$ recombinant sAPP $\alpha$ during GSIS assays demonstrated a significant potentiation of insulin secretion using a range of glucose concentrations (Fig. 9D)

\section{Discussion}

In this study, we report the presence of APP in pancreatic tissue, including the detection of APP within insulinproducing pancreatic $\beta$ cells. We have confirmed the presence of pancreatic islet APP expression in both C57BL/6 mice and human samples, demonstrating this pattern of APP expression is confirmed across species. Interestingly, we observed APP is overexpressed within the pancreatic islets of the APP/PS1 mouse model of AD. This mouse model of $\mathrm{AD}$ uses the mouse prion promoter to drive human APP transgene expression. This finding indicates that the prion promoter itself may be a useful tool for driving robust gene expression of target genes specifically within the endocrine compartment of the pancreas. It has recently been reported that a $3 \times \mathrm{Tg}$ - $\mathrm{AD}$ model of $\mathrm{AD}$, which uses Thy 1.2 promoter, also overexpresses human APP within pancreatic islets (Vandal et al. 2015). Because of the similarity in gene expression and phenotype between pancreatic islets and neurons, it is likely that numerous genetic elements, which drive high expression of genes in the central nervous system will also result in robust islet gene expression (Moller et al. 1992, Atouf et al. 1997, Martens et al. 2011).

Despite the robust overexpression of human mutant APP within the pancreatic islets of the APP/PS1 mouse, we were unable to detect the presence of monomeric human $A \beta, A \beta$ oligomers, or fibrils within APP/PS1 pancreatic tissue or islet cultures by ELISA or immunohistochemistry. This is in agreement with previous reports suggesting $\beta$-secretase activity is not present in pancreatic tissue extractions despite the presence of BACE1 RNA (Sinha et al. 1999, Ehehalt et al. 2002, Mowrer \& Wolfe 2008). In 2002, Ehehalt et al. described a shorter isoform of BACE1 RNA termed BACE1C in the pancreas along with the more well-known BACE1A isoform. BACE1C lacked detectable $\beta$-secretase activity in their assays, suggesting that pancreatic tissue may not produce $A \beta$, in part, because of the presence of this enzymatically inactive splice variant. However, BACE1A is still the dominant isoform of BACE1 found in the pancreas so alternative splicing cannot be the sole reason for this phenomenon. In 2008, Mowrer and Wolfe described similar alternative splicing of BACE1 in the pancreas relative to the brain, but also noted that this alone was not sufficient to explain the lack of BACE1 activity in pancreatic tissue. These authors postulated that pancreatic BACE1 is inactive due to post-translational processing mechanisms. Indeed, it has been shown that BACE1 in the pancreas and other tissues undergoes differential proteolytic processing compared to the brain resulting in lower or undetectable levels of the BACE1 holoprotein (Huse et al. 2003). Instead of $\beta$-secretasemediated APP processing, our data suggest that APP in pancreatic islets is processed by $\alpha$-secretase activity to release sAPP $\alpha$. This is clearly in contrast to the CNS where both forms of APP processing occur. We were also unable to detect plaque deposition in human pancreas sections using the anti- $\mathrm{A} \beta$ antibody, 4G8. It is possible that pancreatic islets could be affected by circulating concentrations of $A \beta$ rather than locally produced $A \beta$.

To study the significance of APP in pancreatic islet function, we examined two-month-old WT, APP-/- and

Published by Bioscientifica Ltd 
APP/PS1 animals for differences in glucose tolerance by oral gavage. This time point was important for assessing the role of islet APP in glucose tolerance because it is well before $A \beta$ deposits are known to form in the CNS of the APP/PS1 mouse. A $\beta$ oligomers or overexpression of the A $\beta$ producing enzyme BACE1 in the brain have recently been demonstrated as sufficient to induce peripheral metabolic dysregulation (Clarke et al. 2015, Plucinska et al. 2016). We detected no significant differences in glucose tolerance across strain, indicating ablation or overexpression of mutant APP does not severely compromise glucose homeostasis mechanisms or severely impair islet function at two months of age. Multiple-organ systems such as liver and kidney gluconeogenesis and muscle glucose uptake are involved in glucose homeostasis; thus, the effect of overexpression or ablation of pancreatic islet APP on blood glucose levels during glucose tolerance testing may be masked by glucose-regulating compensatory mechanisms in other organs. In addition to glucose tolerance testing, we also measured the pancreatic insulin and glucagon content by ELISA. Our results indicate that while total insulin content was unchanged, total pancreatic glucagon levels and glucagon immunostaining were significantly attenuated in animals expressing the APP/PS1 transgenes, suggesting that overexpression of mutant APP or presenilin in pancreatic islets may alter the development of $\alpha$-cells or affect their secretory functions. BACE2 levels were also diminished in the APP/PS1 animals, further suggesting that the APP/PS1 mice may have fewer pancreatic $\alpha$ cells. Future work requiring, perhaps stereologic assessment may provide a clearer indication of changes in total $\alpha$ cell numbers in the APP/PS1 compared to WT mice. One possible mechanism for a change in $\alpha$ cell number could be through alterations in Notch biology. Presenilin is part of the $\gamma$-secretase complex, which cleaves the Notch protein to liberate the biologically active NICD fragment. NICD then enters the nucleus where it affects the transcription (Chan \& Jan 1999). Notch signaling is thought to play a critical role in the normal development of the endocrine pancreas suggesting that mutant presenilin expression in the pancreas may indeed influence this biology (Jensen et al. 2000, Hald et al. 2003, Murtaugh et al. 2003).

Our examinations of pancreatic protein content in two-month-old animals revealed changes in the levels of IDE, GLUT4 and BACE2. Animals lacking the APP gene showed increased levels of IDE and GLUT4, while $\mathrm{APP}^{-/-}$and APP/PS1 animals showed reduced BACE2 levels compared to wild type in Western blot. IDE has been identified as an enzyme capable of degrading $A \beta$ and amylin in addition to insulin. These functions may be important in the pancreas, as inhibition of IDE has been shown to enhance toxicity of islet amylin (Bennett et al. 2003). GLUT4 is considered the insulin responsive glucose transporter and is well known for its role in muscle and fat tissue. Recent studies have presented evidence that both SAPP and A $\beta$ may influence the cellular localization of GLUT4 (Hamilton et al. 2014, Oliveira et al. 2015). BACE2 has been previously implicated as both an APP cleaving enzyme and regulator of $\beta$ cell function through the cleavage of the transmembrane protein TMEM27 (Esterhazy et al. 2011). It has been proposed that full length TMEM27 supports beta cell growth and insulin secretion, thus blocking its cleavage by inhibiting BACE2 activity may represent a therapeutic strategy to control blood glucose in diabetic patients (Southan 2013).

We also examined protein content of primary islet cultures from 12 month old WT, APP-/-, and APP/PS1 animals. Similar to whole pancreas extracts, IDE was present at higher levels in APP-/- compared to WT controls. This indicates that APP may play a role in negatively regulating the expression of IDE, or that differences in the APP-/- animals lead to upregulated IDE expression. We could not detect GLUT4 in our islet lysates; however, GLUT4 is not considered a major glucose transporter in the pancreatic endocrine cells and differences observed in whole pancreas were likely from other cell types. BACE2 levels were not significantly different in islets from transgenic animals compared to controls, which is in contrast to both our immunohistochemistry and whole pancreas Western blot results. This could be in part due to the process of pancreatic islet isolation in which the pancreas is digested with proteases to liberate the islets from exocrine tissue. It is likely that this isolation process would affect the cells at the islet periphery expressing BACE2. Alternatively, some BACE2 in whole pancreatic extracts may be due to the contribution of other cell types.

Although higher glucose culture concentrations are reported to improve islet culture and reduce apoptosis, we chose to avoid high glucose levels that may influence APP expression or processing. Several lines of evidence suggest that culturing cells in high glucose concentrations can alter APP processing and affect APP protein levels (Yang et al. 2013, Lee et al. 2016). Additionally, a recent study utilizing glucose clamps to sustain hyperglycemia demonstrates that increasing glucose concentrations in vivo alters APP processing to influence A $\beta$ levels in the CSF (Macauley et al. 2015). We considered the implications of

Published by Bioscientifica Ltd 
these studies and thus $5 \mathrm{mM}$ glucose was selected for our paradigm. We avoided larger islets with necrotic centers in an attempt to minimize artifacts induced by cell death from lower glucose concentrations. However, since islet glucose concentration exposure in vivo may be well above $5 \mathrm{mM}$, there was a concern that our primary islet sAPP $\alpha$ stimulation paradigm was superimposed upon a glucosedeficient condition. To verify that sAPP $\alpha$-stimulated insulin secretion at higher glucose concentrations, we employed the MIN6 cell line to demonstrate that insulin secretion was still potentiated at $16.7 \mathrm{mM}$ glucose concentration. Future studies will require further optimization of islet culture conditions including higher glucose concentrations. In addition, it is important to remember that although the wild-type mice are littermate controls of the APP/PS1 mice in our study, the $\mathrm{APP}-/-$ mice were derived from a homozygous colony and comparison to the other two lines is potentially limited by this. Nevertheless, these data suggest changes in pancreatic APP content or processing may result in alterations in the levels of proteins important to pancreatic physiology and influence the pathology of pancreatic diseases.

Interestingly, our immunohistochemistry data indicated that primary antibodies directed against BACE2 showed increased binding in pancreatic $\alpha$ cells compared to $\beta$ cells in both mouse and human tissue. This is particularly interesting as BACE inhibitors are actively being explored as a therapeutic strategy in $\mathrm{AD}$ (Kennedy et al. 2016). Our detection of BACE2 in $\alpha$ cells is in contrast to reports indicating the highest pancreatic BACE2 expression is found within pancreatic $\beta$ cells (Finzi et al. 2008, Esterhazy et al. 2011). A likely reason for this discrepancy is the binding site of the antibody used to detect pancreatic BACE2. BACE1 and BACE2 share a high degree of sequence similarity, and several alternatively spliced transcripts of BACE1 are known to be present in the pancreas (Ehehalt et al. 2002, Mowrer \& Wolfe 2008). In agreement with our findings, a recent study by Segerstolpe and coworkers also observed higher expression of BACE2 in $\alpha$ cells relative to $\beta$ cells through single-cell transcription profiling, which can be viewed at the online database at http://sandberg.cmb.ki.se/pancreas/ (Segerstolpe et al. 2016). In this study, we utilized a polyclonal antibody raised against the BACE2 prodomain sequence not present in the BACE1 sequence. Prodomain cleavage is thought to be an essential step in the activation of the BACE2 proenzyme; thus, our immunohistochemistry results could indicate differences in BACE2 activation in $\alpha$ and $\beta$ cells (Hussain et al. 2000, 2001).
Our assessments of isolated pancreatic islets demonstrate both endogenous murine APP and transgenic human APP are released as SAPP into culture media from WT and APP/PS1 mouse islets, respectively. We also observed modest but significant differences in the insulinsecretion properties of islets overexpressing or lacking APP compared to WT controls, suggesting the presence of APP may influence the basic functional properties of $\beta$ cells in vitro. However, a lack of detectable differences in $\mathrm{APP}^{-/-}$and APP/PS1 animals compared to WT controls in glucose tolerance testing at two months of age suggests APP is not essential for normal islet insulin secretion or glucose homeostasis in vivo.

sAPP has been shown to exert effects on a variety of cell types. In the central nervous system, sAPP is thought to promote neurite outgrowth and influence the differentiation of neural stem cells (Jin et al. 1994, Porayette et al. 2009, Freude et al. 2011, Baratchi et al. 2012). sAPP has also been implicated as having a growth-enhancing effect in pancreatic cancer, in addition to altering the proliferation rate of other cell types (Hansel et al. 2003, Demars et al. 2011, Woods \& Padmanabhan 2013). Our data indicate that recombinant sAPP $\alpha$ modestly potentiates insulin secretion in pancreatic islets from both mice and humans in vitro. This suggests that sAPP may exert effects on $\beta$ cell function, potentially by acting on cell surface receptors in an autocrine fashion. The mechanism through which sAPP exerts its biological effects is uncertain and may be due to interactions with several proteins. Several studies have identified putative cell-surface receptors for sAPP. These include the P75 neurotrophic receptor, LRP1, as well as APP itself (Kounnas et al. 1995, Hasebe et al. 2013). The putative receptors and biological effects of sAPP signaling have recently been extensively reviewed (Habib et al. 2017). Stimulation of these cell-surface receptors by sAPP may influence the survival or phenotype of islets in culture. Indeed, recombinant sAPP has been shown to induce cell signaling cascades, which may account for its effects on cultured islets (Bodles \& Barger 2005, Jimenez et al. 2011, Deng et al. 2015). Our future work will focus on identifying signaling cascades and downstream effects induced in pancreatic endocrine cells by both APP and sAPP.

To our knowledge, our data are the first report showing SAPP is released from both primary mouse and human islet cultures into culture media. We also present new data indicating expression of the BACE2 protein in pancreatic $\alpha$ cells. Findings from this study contribute to the basic understanding of amyloid precursor protein and pancreatic islet physiology.

Published by Bioscientifica Ltd. 


\section{Supplementary data}

This is linked to the online version of the paper at http://dx.doi.org/10.1530/ JOE-17-0122.

\section{Declaration of interest}

The authors declare that there is no conflict of interest that could be perceived as prejudicing the impartiality of the research reported.

\section{Funding}

This study was supported by NIH R01AG042819.

\section{Acknowledgements}

The authors thank Dr Kumi Combs (University of North Dakota) for assistance with GSIS assays. They thank Dr Radhika H Muzumdar (University of Pittsburgh School of Medicine) for helpful suggestions involving the culture of MIN6 cells and critical analysis of this work.

\section{References}

Alzheimer's Association 20152015 Alzheimer's disease facts and figures. Alzheimers \& Dementia 11 332-384. (doi:10.1016/j.jalz.2015.02.003)

Arai H, Lee VM, Messinger ML, Greenberg BD, Lowery DE \& Trojanowski JQ 1991 Expression patterns of beta-amyloid precursor protein (betaAPP) in neural and nonneural human tissues from Alzheimer's disease and control subjects. Annals of Neurology 30 686-693. (doi:10.1002/ ana.410300509)

Ashcroft FM \& Rorsman P 2012 Diabetes mellitus and the beta cell: the last ten years. Cell 148 1160-1171. (doi:10.1016/j.cell.2012.02.010)

Atouf F, Czernichow P \& Scharfmann R 1997 Expression of neuronal traits in pancreatic beta cells. Implication of neuron-restrictive silencing factor/repressor element silencing transcription factor, a neuron-restrictive silencer. Journal of Biological Chemistry 272 1929-1934. (doi:10.1074/jbc.272.3.1929)

Bailey AR, Giunta BN, Obregon D, Nikolic WV, Tian J, Sanberg CD, Sutton DT \& Tan J 2008 Peripheral biomarkers in Autism: secreted amyloid precursor protein-alpha as a probable key player in early diagnosis. International Journal of Clinical and Experimental Medicine $\mathbf{1}$ 338-344.

Baratchi S, Evans J, Tate WP, Abraham WC \& Connor B 2012 Secreted amyloid precursor proteins promote proliferation and glial differentiation of adult hippocampal neural progenitor cells. Hippocampus 22 1517-1527. (doi:10.1002/hipo.20988)

Bedse G, Di Domenico F, Serviddio G \& Cassano T 2015 Aberrant insulin signaling in Alzheimer's disease: current knowledge. Frontiers in Neuroscience 9204.

Beer J, Masters CL \& Beyreuther K 1995 Cells from peripheral tissues that exhibit high APP expression are characterized by their high membrane fusion activity. Neurodegeneration 4 51-59. (doi:10.1006/ neur.1995.0006)

Bennett BD, Babu-Khan S, Loeloff R, Louis JC, Curran E, Citron M \& Vassar R 2000 Expression analysis of BACE2 in brain and peripheral tissues. Journal of Biological Chemistry 275 20647-20651. (doi:10.1074/ jbc.M002688200)

Bennett RG, Hamel FG \& Duckworth WC 2003 An insulin-degrading enzyme inhibitor decreases amylin degradation, increases amylin-induced cytotoxicity, and increases amyloid formation in insulinoma cell cultures. Diabetes 52 2315-2320. (doi:10.2337/ diabetes.52.9.2315)
Biessels GJ, Staekenborg S, Brunner E, Brayne C \& Scheltens P 2006 Risk of dementia in diabetes mellitus: a systematic review. Lancet Neurology 5 64-74. (doi:10.1016/S1474-4422(05)70284-2)

Bodles AM \& Barger SW 2005 Secreted beta-amyloid precursor protein activates microglia via JNK and p38-MAPK. Neurobiology of Aging 26 9-16. (doi:10.1016/j.neurobiolaging.2004.02.022)

Bradford MM 1976 A rapid and sensitive method for the quantitation of microgram quantities of protein utilizing the principle of protein-dye binding. Analytical Biochemistry 72 248-254. (doi:10.1016/00032697(76)90527-3)

Cabrera O, Berman DM, Kenyon NS, Ricordi C, Berggren PO \& Caicedo A 2006 The unique cytoarchitecture of human pancreatic islets has implications for islet cell function. PNAS 103 2334-2339. (doi:10.1073/pnas.0510790103)

Chan YM \& Jan YN 1999 Presenilins, processing of beta-amyloid precursor protein, and notch signaling. Neuron 23 201-204. (doi:10.1016/S0896-6273(00)80771-0)

Clarke JR, Lyra ESNM, Figueiredo CP, Frozza RL, Ledo JH, Beckman D, Katashima CK, Razolli D, Carvalho BM, Frazao R, et al. 2015 Alzheimer-associated Abeta oligomers impact the central nervous system to induce peripheral metabolic deregulation. EMBO Molecular Medicine 7 190-210. (doi:10.15252/emmm.201404183)

Claxton A, Baker LD, Hanson A, Trittschuh EH, Cholerton B, Morgan A, Callaghan M, Arbuckle M, Behl C \& Craft S 2015 Long-acting intranasal insulin detemir improves cognition for adults with mild cognitive impairment or early-stage Alzheimer's disease dementia. Journal of Alzheimer's Disease 44 897-906.

Crane PK, Walker R, Hubbard RA, Li G, Nathan DM, Zheng H, Haneuse S, Craft S, Montine TJ, Kahn SE, et al. 2013 Glucose levels and risk of dementia. New England Journal of Medicine 369 540-548. (doi:10.1056/ NEJMoa1215740)

De Felice FG \& Ferreira ST 2014 Inflammation, defective insulin signaling, and mitochondrial dysfunction as common molecular denominators connecting type 2 diabetes to Alzheimer disease. Diabetes 63 2262-2272. (doi:10.2337/db13-1954)

de la Monte SM 2014 Type 3 diabetes is sporadic Alzheimers disease: mini-review. European Neuropsychopharmacology 24 1954-1960. (doi:10.1016/j.euroneuro.2014.06.008)

Demars MP, Bartholomew A, Strakova Z \& Lazarov O 2011 Soluble amyloid precursor protein: a novel proliferation factor of adult progenitor cells of ectodermal and mesodermal origin. Stem Cell Research and Therapy 2 36. (doi:10.1186/scrt77)

Deng J, Habib A, Obregon DF, Barger SW, Giunta B, Wang YJ, Hou H, Sawmiller D \& Tan J 2015 Soluble amyloid precursor protein alpha inhibits tau phosphorylation through modulation of GSK3beta signaling pathway. Journal of Neurochemistry 135 630-637. (doi:10.1111/jnc.13351)

Dhawan G, Floden AM \& Combs CK 2012 Amyloid-beta oligomers stimulate microglia through a tyrosine kinase dependent mechanism. Neurobiology of Aging 33 2247-2261. (doi:10.1016/j. neurobiolaging.2011.10.027)

Ehehalt R, Michel B, De Pietri Tonelli D, Zacchetti D, Simons K \& Keller P 2002 Splice variants of the beta-site APP-cleaving enzyme BACE1 in human brain and pancreas. Biochemical and Biophysical Research Communications 293 30-37. (doi:10.1016/S0006291X(02)00169-9)

Esterhazy D, Stutzer I, Wang H, Rechsteiner MP, Beauchamp J, Dobeli H, Hilpert H, Matile H, Prummer M, Schmidt A, et al. 2011 Bace2 is a beta cell-enriched protease that regulates pancreatic beta cell function and mass. Cell Metabolism 14 365-377. (doi:10.1016/j. cmet.2011.06.018)

Figueroa DJ, Shi XP, Gardell SJ \& Austin CP 2001 Abetapp secretases are co-expressed with Abetapp in the pancreatic islets. Journal of Alzheimer's Disease 3 393-396. (doi:10.3233/JAD-2001-3405)

Finzi G, Franzi F, Placidi C, Acquati F, Palumbo E, Russo A, Taramelli $\mathrm{R}$, Sessa F \& La Rosa S 2008 BACE2 is stored in secretory granules

Published by Bioscientifica Ltd http://joe.endocrinology-journals.org

DOI: $10.1530 / \mathrm{JOE}-17-0122$
() 2017 Society for Endocrinology Printed in Great Britain 
of mouse and rat pancreatic beta cells. Ultrastructural Pathology 32 246-251. (doi:10.1080/01913120802486217)

Freude KK, Penjwini M, Davis JL, LaFerla FM \& Blurton-Jones M 2011 Soluble amyloid precursor protein induces rapid neural differentiation of human embryonic stem cells. Journal of Biological Chemistry 286 24264-24274. (doi:10.1074/jbc.M111.227421)

Goldgaber D, Lerman MI, McBride WO, Saffiotti U \& Gajdusek DC 1987 Isolation, characterization, and chromosomal localization of human brain cDNA clones coding for the precursor of the amyloid of brain in Alzheimer's disease, Down's syndrome and aging. Journal of Neural Transmission Supplement 24 23-28.

Gordon MN, Holcomb LA, Jantzen PT, DiCarlo G, Wilcock D, Boyett KW, Connor K, Melachrino J, O'Callaghan JP \& Morgan D 2002 Time course of the development of Alzheimer-like pathology in the doubly transgenic PS1+APP mouse. Experimental Neurology 173 183-195. (doi:10.1006/exnr.2001.7754)

Habib A, Sawmiller D \& Tan J 2017 Restoring soluble amyloid precursor protein alpha functions as a potential treatment for alzheimer's disease. Journal of Neuroscience Research 95 973-991. (doi:10.1002/jnr.23823)

Hald J, Hjorth JP, German MS, Madsen OD, Serup P \& Jensen J 2003 Activated Notch1 prevents differentiation of pancreatic acinar cells and attenuate endocrine development. Developmental Biology 260 426-437. (doi:10.1016/S0012-1606(03)00326-9)

Hamilton DL, Findlay JA, Montagut G, Meakin PJ, Bestow D, Jalicy SM \& Ashford ML 2014 Altered amyloid precursor protein processing regulates glucose uptake and oxidation in cultured rodent myotubes. Diabetologia 57 1684-1692. (doi:10.1007/ s00125-014-3269-x)

Hansel DE, Rahman A, Wehner S, Herzog V, Yeo CJ \& Maitra A 2003 Increased expression and processing of the Alzheimer amyloid precursor protein in pancreatic cancer may influence cellular proliferation. Cancer Research 63 7032-7037.

Hasebe N, Fujita Y, Ueno M, Yoshimura K, Fujino Y \& Yamashita T 2013 Soluble beta-amyloid precursor protein alpha binds to p75 neurotrophin receptor to promote neurite outgrowth. PLOS ONE $\mathbf{8}$ e82321. (doi:10.1371/journal.pone.0082321)

Ho L, Qin W, Pompl PN, Xiang Z, Wang J, Zhao Z, Peng Y, Cambareri G, Rocher A, Mobbs CV, et al. 2004 Diet-induced insulin resistance promotes amyloidosis in a transgenic mouse model of Alzheimer's disease. FASEB Journal 18 902-904.

Holscher C 2014 First clinical data of the neuroprotective effects of nasal insulin application in patients with Alzheimer's disease. Alzheimers Dement 10 S33-S37. (doi:10.1016/j.jalz.2013.12.006)

Hoyer S 1991 Abnormalities of glucose metabolism in Alzheimer's disease. Annals of the New York Academy of Sciences 640 53-58. (doi:10.1111/j.1749-6632.1991.tb00190.x)

Huse JT, Byant D, Yang Y, Pijak DS, D'Souza I, Lah JJ, Lee VM, Doms RW \& Cook DG 2003 Endoproteolysis of beta-secretase (beta-site amyloid precursor protein-cleaving enzyme) within its catalytic domain. A potential mechanism for regulation. Journal of Biological Chemistry 278 17141-17149. (doi:10.1074/jbc.M213303200)

Hussain I, Powell DJ, Howlett DR, Chapman GA, Gilmour L, Murdock PR, Tew DG, Meek TD, Chapman C, Schneider K, et al. 2000 ASP1 (BACE2) cleaves the amyloid precursor protein at the beta-secretase site. Molecular and Cellular Neuroscience 16 609-619. (doi:10.1006/ mone.2000.0884)

Hussain I, Christie G, Schneider K, Moore S \& Dingwall C 2001 Prodomain processing of Asp1 (BACE2) is autocatalytic. Journal of Biological Chemistry 276 23322-23328. (doi:10.1074/jbc. M101069200)

Jensen J, Heller RS, Funder-Nielsen T, Pedersen EE, Lindsell C, Weinmaster G, Madsen OD \& Serup P 2000 Independent development of pancreatic alpha- and beta-cells from neurogenin3expressing precursors: a role for the notch pathway in repression of premature differentiation. Diabetes 49 163-176. (doi:10.2337/ diabetes.49.2.163)
Jimenez S, Baglietto-Vargas D, Caballero C, Moreno-Gonzalez I, Torres M, Sanchez-Varo R, Ruano D, Vizuete M, Gutierrez A \& Vitorica J 2008 Inflammatory response in the hippocampus of PS1M146L/APP751SL mouse model of Alzheimer's disease: agedependent switch in the microglial phenotype from alternative to classic. Journal of Neuroscience 28 11650-11661. (doi:10.1523/ JNEUROSCI.3024-08.2008)

Jimenez S, Torres M, Vizuete M, Sanchez-Varo R, Sanchez-Mejias E, Trujillo-Estrada L, Carmona-Cuenca I, Caballero C, Ruano D, Gutierrez A, et al. 2011 Age-dependent accumulation of soluble amyloid beta (Abeta) oligomers reverses the neuroprotective effect of soluble amyloid precursor protein-alpha (sAPP(alpha)) by modulating phosphatidylinositol 3-kinase (PI3K)/Akt-GSK-3beta pathway in Alzheimer mouse model. Journal of Biological Chemistry 286 18414-18425. (doi:10.1074/jbc.M110.209718)

Jin LW, Ninomiya H, Roch JM, Schubert D, Masliah E, Otero DA \& Saitoh T 1994 Peptides containing the RERMS sequence of amyloid beta/A4 protein precursor bind cell surface and promote neurite extension. Journal of Neuroscience 14 5461-5470.

Julien C, Tremblay C, Phivilay A, Berthiaume L, Emond V, Julien P \& Calon F 2010 High-fat diet aggravates amyloid-beta and tau pathologies in the 3xTg-AD mouse model. Neurobiology Aging 31 1516-1531. (doi:10.1016/j.neurobiolaging.2008.08.022)

Kennedy ME, Stamford AW, Chen X, Cox K, Cumming JN, Dockendorf MF, Egan M, Ereshefsky L, Hodgson RA, Hyde LA, et al. 2016 The BACE1 inhibitor verubecestat (MK-8931) reduces CNS beta-amyloid in animal models and in Alzheimer's disease patients. Science Translational Medicine 8 363ra150. (doi:10.1126/scitranslmed. aad9704)

Konig G, Monning U, Czech C, Prior R, Banati R, Schreiter-Gasser U, Bauer J, Masters CL \& Beyreuther K 1992 Identification and differential expression of a novel alternative splice isoform of the beta A4 amyloid precursor protein (APP) mRNA in leukocytes and brain microglial cells. Journal of Biological Chemistry 267 10804-10809.

Kounnas MZ, Moir RD, Rebeck GW, Bush AI, Argraves WS, Tanzi RE, Hyman BT \& Strickland DK 1995 LDL receptor-related protein, a multifunctional ApoE receptor, binds secreted beta-amyloid precursor protein and mediates its degradation. Cell 82 331-340. (doi:10.1016/0092-8674(95)90320-8)

Lee HJ, Ryu JM, Jung YH, Lee SJ, Kim JY, Lee SH, Hwang IK, Seong JK \& Han HJ 2016 High glucose upregulates BACE1-mediated Abeta production through ROS-dependent HIF-1alpha and LXRalpha/ ABCA1-regulated lipid raft reorganization in SK-N-MC cells. Science Reports 6 36746. (doi:10.1038/srep36746)

Lorenzo A, Razzaboni B, Weir GC \& Yankner BA 1994 Pancreatic islet cell toxicity of amylin associated with type- 2 diabetes mellitus. Nature 368 756-760. (doi:10.1038/368756a0)

Macauley SL, Stanley M, Caesar EE, Yamada SA, Raichle ME, Perez R, Mahan TE, Sutphen CL \& Holtzman DM 2015 Hyperglycemia modulates extracellular amyloid-beta concentrations and neuronal activity in vivo. Journal of Clinical Investigation 125 2463-2467. (doi:10.1172/JCI79742)

Manocha GD, Floden AM, Rausch K, Kulas JA, McGregor BA, Rojanathammanee L, Puig KR, Puig KL, Karki S, Nichols MR, et al. 2016 APP regulates microglial phenotype in a mouse model of Alzheimer's disease. Journal of Neuroscience 36 8471-8486. (doi:10.1523/JNEUROSCI.4654-15.2016)

Martens GA, Jiang L, Hellemans KH, Stange G, Heimberg H, Nielsen FC, Sand O, Van Helden J, Van Lommel L, Schuit F, et al. 2011 Clusters of conserved beta cell marker genes for assessment of beta cell phenotype. PLOS ONE 6 e24134. (doi:10.1371/journal.pone.0024134)

Miklossy J, Qing H, Radenovic A, Kis A, Vileno B, Laszlo F, Miller L, Martins RN, Waeber G, Mooser V, et al. 2010 Beta amyloid and hyperphosphorylated tau deposits in the pancreas in type 2 diabetes. Neurobiology of Aging 31 1503-1515. (doi:10.1016/j. neurobiolaging.2008.08.019) 
Moller CJ, Christgau S, Williamson MR, Madsen OD, Niu ZP, Bock E \& Baekkeskov S 1992 Differential expression of neural cell adhesion molecule and cadherins in pancreatic islets, glucagonomas, and insulinomas. Molecular Endocrinology 6 1332-1342.

Morales-Corraliza J, Wong H, Mazzella MJ, Che S, Lee SH, Petkova E, Wagner JD, Hemby SE, Ginsberg SD \& Mathews PM 2016 Brain-wide insulin resistance, tau phosphorylation changes, and hippocampal neprilysin and amyloid-beta alterations in a monkey model of type 1 diabetes. Journal of Neuroscience 36 4248-4258. (doi:10.1523/ JNEUROSCI.4640-14.2016)

Mowrer KR \& Wolfe MS 2008 Promotion of BACE1 mRNA alternative splicing reduces amyloid beta-peptide production. Journal of Biological Chemistry 283 18694-18701. (doi:10.1074/jbc.M801322200)

Murtaugh LC, Stanger BZ, Kwan KM \& Melton DA 2003 Notch signaling controls multiple steps of pancreatic differentiation. PNAS $\mathbf{1 0 0}$ 14920-14925. (doi:10.1073/pnas.2436557100)

Needham BE, Wlodek ME, Ciccotosto GD, Fam BC, Masters CL, Proietto J, Andrikopoulos S \& Cappai R 2008 Identification of the Alzheimer's disease amyloid precursor protein (APP) and its homologue APLP2 as essential modulators of glucose and insulin homeostasis and growth. Journal of Pathology 215 155-163. (doi:10.1002/path.2343)

Oliveira LT, Leon GV, Provance DW Jr, de Mello FG, Sorenson MM \& Salerno VP 2015 Exogenous beta-amyloid peptide interferes with GLUT4 localization in neurons. Brain Research 1615 42-50. (doi:10.1016/j.brainres.2015.04.026)

Oskarsson ME, Paulsson JF, Schultz SW, Ingelsson M, Westermark P \& Westermark GT 2015 In vivo seeding and cross-seeding of localized amyloidosis: a molecular link between type 2 diabetes and Alzheimer disease. American Journal of Pathology 185 834-846. (doi:10.1016/j. ajpath.2014.11.016)

Plucinska K, Dekeryte R, Koss D, Shearer K, Mody N, Whitfield PD, Doherty MK, Mingarelli M, Welch A, Riedel G, et al. 2016 Neuronal human BACE1 knockin induces systemic diabetes in mice. Diabetologia 59 1513-1523. (doi:10.1007/s00125-016-3960-1)

Porayette P, Gallego MJ, Kaltcheva MM, Bowen RL, Vadakkadath Meethal S \& Atwood CS 2009 Differential processing of amyloid-beta precursor protein directs human embryonic stem cell proliferation and differentiation into neuronal precursor cells. Journal of Biological Chemistry 284 23806-23817. (doi:10.1074/jbc.M109.026328)

Puig KL \& Combs CK 2013 Expression and function of APP and its metabolites outside the central nervous system. Experimental Gerontology 48 608-611. (doi:10.1016/j.exger.2012.07.009)

Puig KL, Swigost AJ, Zhou X, Sens MA \& Combs CK 2012 Amyloid precursor protein expression modulates intestine immune phenotype. Journal of Neuroimmune Pharmacology 7 215-230. (doi:10.1007/ s11481-011-9327-y)

Puig KL, Lutz BM, Urquhart SA, Rebel AA, Zhou X, Manocha GD, Sens M, Tuteja AK, Foster NL \& Combs CK 2015 Overexpression of mutant amyloid-beta protein precursor and presenilin 1 modulates enteric nervous system. Journal of Alzheimer's Disease 44 1263-1278.

Qiu WQ, Walsh DM, Ye Z, Vekrellis K, Zhang J, Podlisny MB, Rosner MR, Safavi A, Hersh LB \& Selkoe DJ 1998 Insulin-degrading enzyme regulates extracellular levels of amyloid beta-protein by degradation. Journal of Biological Chemistry 273 32730-32738. (doi:10.1074/ jbc.273.49.32730)

Reger MA, Watson GS, Green PS, Wilkinson CW, Baker LD, Cholerton B, Fishel MA, Plymate SR, Breitner JC, DeGroodt W, et al. 2008 Intranasal insulin improves cognition and modulates beta-amyloid in early AD. Neurology 70 440-448. (doi:10.1212/01.WNL.0000265401.62434.36)

Schlossmacher MG, Ostaszewski BL, Hecker LI, Celi A, Haass C, Chin D, Lieberburg I, Furie BC, Furie B \& Selkoe DJ 1992 Detection of distinct isoform patterns of the beta-amyloid precursor protein in human platelets and lymphocytes. Neurobiology of Aging 13 421-434. (doi:10.1016/0197-4580(92)90117-G)

Segerstolpe A, Palasantza A, Eliasson P, Andersson EM, Andreasson AC, Sun X, Picelli S, Sabirsh A, Clausen M, Bjursell MK, et al. 2016 Single- cell transcriptome profiling of human pancreatic islets in health and Type 2 diabetes. Cell Metabolism 24 593-607. (doi:10.1016/j. cmet.2016.08.020)

Selkoe DJ, Podlisny MB, Joachim CL, Vickers EA, Lee G, Fritz LC \& Oltersdorf T 1988 Beta-amyloid precursor protein of Alzheimer disease occurs as 110- to 135-kilodalton membrane-associated proteins in neural and nonneural tissues. PNAS $\mathbf{8 5} 7341-7345$ (doi:10.1073/pnas.85.19.7341)

Shoji M, Kawarabayashi T, Sato M, Sasaki A, Matsubara E, Igeta Y, Kanai M, Tomidokoro Y, Shizuka M, Ishiguro K, et al. 1998 Accumulation of amyloid beta protein in transgenic mice. Neurobiology of Aging 19 S59-S63. (doi:10.1016/S0197-4580(98)00043-8)

Shoji M, Kawarabayashi T, Sato M, Sasaki A, Saido TC, Matsubara E, Tomidokoro Y, Kanai M, Shizuka M, Ishiguro K, et al. 2000 Agerelated amyloid beta protein accumulation induces cellular death and macrophage activation in transgenic mice. Journal of Pathology 191 93-101. (doi:10.1002/(SICI)1096-9896(200005)191:1<93::AIDPATH567>3.0.CO;2-Q)

Sinha S, Anderson JP, Barbour R, Basi GS, Caccavello R, Davis D, Doan M, Dovey HF, Frigon N, Hong J, et al. 1999 Purification and cloning of amyloid precursor protein beta-secretase from human brain. Nature 402 537-540. (doi:10.1038/990114)

Sondag CM \& Combs CK 2010 Adhesion of monocytes to type I collagen stimulates an APP-dependent proinflammatory signaling response and release of Abeta1-40. Journal of Neuroinflammation 722. (doi:10.1186/1742-2094-7-22)

Southan C 2013 BACE2 as a new diabetes target: a patent review (2010 2012). Expert Opinion on Therapeutic Patents 23 649-663. (doi:10.1517/ 13543776.2013.780032)

Stull ND, Breite A, McCarthy R, Tersey SA \& Mirmira RG 2012 Mouse islet of Langerhans isolation using a combination of purified collagenase and neutral protease. Journal of Visualized Experiments. 67 e4137. (doi:10.3791/4137)

Szot GL, Koudria P \& Bluestone JA 2007 Murine pancreatic islet isolation. Journal of Visualized Experiments 7 e255. (doi:10.3791/255)

Takeda S, Sato N, Uchio-Yamada K, Sawada K, Kunieda T, Takeuchi D, Kurinami H, Shinohara M, Rakugi H \& Morishita R 2010 Diabetesaccelerated memory dysfunction via cerebrovascular inflammation and Abeta deposition in an Alzheimer mouse model with diabetes. PNAS 107 7036-7041. (doi:10.1073/pnas.1000645107)

Talbot K, Wang HY, Kazi H, Han LY, Bakshi KP, Stucky A, Fuino RL, Kawaguchi KR, Samoyedny AJ, Wilson RS, et al. 2012 Demonstrated brain insulin resistance in Alzheimer's disease patients is associated with IGF-1 resistance, IRS-1 dysregulation, and cognitive decline. Journal of Clinical Investigation 122 1316-1338. (doi:10.1172/JCI59903)

Tu Z, Keller MP, Zhang C, Rabaglia ME, Greenawalt DM, Yang X, Wang IM, Dai H, Bruss MD, Lum PY, et al. 2012 Integrative analysis of a cross-loci regulation network identifies App as a gene regulating insulin secretion from pancreatic islets. PLoS Genetics $\mathbf{8}$ e1003107. (doi:10.1371/journal.pgen.1003107)

Vandal M, White PJ, Tremblay C, St-Amour I, Chevrier G, Emond V, Lefrancois D, Virgili J, Planel E, Giguere Y, et al. 2014 Insulin reverses the high-fat diet-induced increase in brain Abeta and improves memory in an animal model of Alzheimer disease. Diabetes 63 4291-4301. (doi:10.2337/db14-0375)

Vandal M, White PJ, Chevrier G, Tremblay C, St-Amour I, Planel E, Marette A \& Calon F 2015 Age-dependent impairment of glucose tolerance in the 3xTg-AD mouse model of Alzheimer's disease. FASEB Journal 29 4273-4284. (doi:10.1096/fj.14-268482)

Wang X, Zheng W, Xie JW, Wang T, Wang SL, Teng WP \& Wang ZY 2010 Insulin deficiency exacerbates cerebral amyloidosis and behavioral deficits in an Alzheimer transgenic mouse model. Molecular Neurodegeneration 5 46. (doi:10.1186/1750-1326-5-46)

Wegiel J, Wisniewski HM, Muzylak M, Tarnawski M, Badmajew E, Nowakowski J, Wang KC, Shoji M, Mondadori C \& Giovanni A 2000 Fibrillar amyloid-beta production, accumulation, and recycling in 
transgenic mice pancreatic acinar cells and macrophages. Amyloid $\mathbf{7}$ 95-104. (doi:10.3109/13506120009146245)

Weidemann A, Konig G, Bunke D, Fischer P, Salbaum JM, Masters CL \& Beyreuther K 1989 Identification, biogenesis, and localization of precursors of Alzheimer's disease A4 amyloid protein. Cell $\mathbf{5 7}$ 115-126. (doi:10.1016/0092-8674(89)90177-3)

Westermark P, Wilander E, Westermark GT \& Johnson KH 1987 Islet amyloid polypeptide-like immunoreactivity in the islet B cells of type 2 (non-insulin-dependent) diabetic and non-diabetic individuals. Diabetologia 30 887-892.

Woods NK \& Padmanabhan J 2013 Inhibition of amyloid precursor protein processing enhances gemcitabine-mediated cytotoxicity in pancreatic cancer cells. Journal of Biological Chemistry 288 30114-30124. (doi:10.1074/jbc.M113.459255)

Yan R, Munzner JB, Shuck ME \& Bienkowski MJ 2001 BACE2 functions as an alternative alpha-secretase in cells. Journal of Biological Chemistry 276 34019-34027. (doi:10.1074/jbc.M105583200)

Yang Y, Wu Y, Zhang S \& Song W 2013 High glucose promotes Abeta production by inhibiting APP degradation. PLOS ONE 8 e69824. (doi:10.1371/journal.pone.0069824)

Zhang H, Hao Y, Manor B, Novak P, Milberg W, Zhang J, Fang J \& Novak V 2015 Intranasal insulin enhanced resting-state functional connectivity of hippocampal regions in type 2 diabetes. Diabetes 64 1025-1034. (doi:10.2337/db14-1000)

Received in final form 6 July 2017

Accepted 13 July 2017

Accepted Preprint published online 14 July 2017
Published by Bioscientifica Ltd 